\title{
Buckling Analysis of Symmetrically Laminated Rectangular Thin Plates under Biaxial Compression
}

\author{
Erkin ALTUNSARAY ${ }^{1}$ \\ İsmail BAYER ${ }^{2}$
}

\begin{abstract}
In this parametric study, the buckling analysis of symmetrically laminated rectangular thin plates subjected to biaxial compression is presented. The simply supported boundary condition is considered at the edges of the symmetrically laminated quasi-isotropic, crossply and angle-ply plates. The Rayleigh-Ritz Method is used to specify the critical buckling load of the plates based on the Classical Laminated Plate Theory (CLPT). A convergence study is achieved by increasing the number of parameters of assumed shape function. Validation of isotropic case is verified. The effects of the lamination types, plate aspect ratios $(\mathrm{a} / \mathrm{b}, \mathrm{b} / \mathrm{a})$ and thickness on the critical buckling load of the laminated plates under bi-axial compression were then investigated. The results were compared with Finite Element Method (FEM) solutions performed by ANSYS software package and fairly good agreement is obtained. Non-dimensional results were tabulated and presented for practical use for designers.
\end{abstract}

Keywords: Bi-axial buckling, symmetrically laminated thin plate, Rayleigh-Ritz Method, Finite Element Method, parametric study.

\section{INTRODUCTION}

Laminated composite thin plates have been extensively used in a diverse field of application in engineering structures such as civil, wind, aerospace, automotive and ship hull and superstructures etc., due to their excellent high strength-to-weight ratio and modulus-toweight ratio. Being a structural element, buckling is a significant problem for these plates. Buckling of composite plates, which is often encountered in such structures, commonly occurs at a low applied stress levels and generates large deformations. Therefore, buckling

\footnotetext{
Note:

- This paper was received onAugust 19, 2019 and accepted for publication by the Editorial Board on April 17, 2020.

- Discussions on this paper will be accepted by January 31, 2022.

- https://doi.org/10.18400/tekderg.606620

1 Dokuz Eylul University, Institute of Marine Sciences and Technology, Izmir, Turkey erkin.altunsaray@deu.edu.tr - https://orcid.org/0000-0003-3099-6059

2 Yildiz Technical University, Department of Naval Architecture and Marine Engineering, Istanbul, Turkey bayer@yildiz.edu.tr - https://orcid.org/0000-0002-8589-671X
} 
of composite plates is a critical problem and focusing on the buckling phenomenon is of importance.

Early studies about uniaxial and biaxial buckling analysis of laminated rectangular composite plates were carried out by several researchers [1-19] before this century. Many researchers have investigated mechanical buckling of composite rectangular plates for the last two decades. Veres and Kollar [20] carried out buckling of orthotropic plates subject to biaxial load based on the Ritz method. Biaxial buckling behavior of anisotropic rectangular plates under simply supported, clamped and mixed boundary conditions was investigated analytically, experimentally and numerically by Romeo and Ferrero [21] and results demonstrated good correlation. Narita and Turvey [22] studied the optimum lay-ups and maximum buckling loads of symmetrically laminated rectangular plates by new layer-wise optimization (LO) iterative procedure. Ni et al. [23] presented buckling behavior for rectangular laminated composite plates subjected to biaxial loading by higher-order shear deformation theory and the pb-2 Ritz method for arbitrary boundary conditions. Shukla et al. [24] performed critical buckling analysis of cross-ply and angle-ply plates under uniaxial and biaxial loading based on the first-order shear deformation theory and von-Karman-type nonlinearity for different boundary conditions. Buckling of cross-ply square plates under uniaxial and biaxial loading on the basis of a unified five-degree-of-freedom shear deformable plate theory was presented by Timarci and Aydogdu [25].

Bert and Malik [26] analyzed buckling of cross-ply plates subject to uniaxial and biaxial compression using classical laminated plate theory, third order shear deformable theory and differential quadrature method for simply supported boundary condition. Qiao and Shan [27] studied buckling analysis of rotationally restrained plates subjected to biaxial load using the Ritz method. Aktaş [28] studied buckling of carbon/epoxy laminated composite plates under biaxial loading using The Veres-Kollar approach [20] and Finite Element Method software ANSYS. Good agreement was obtained between analytical and numerical results. Latalski [29] dealt with the ply thicknesses on optimal design of multi-layered laminated plates under uniaxial and biaxial compression. Sayyad and Ghugal [30] developed a trigonometric shear and normal deformation theory for buckling of isotropic, transversely isotropic, orthotropic composite rectangular plates subject to in-plane compressive forces. Bourada et al. [31] analyzed buckling of isotropic and orthotropic plates subject to uniaxial and biaxial compression by proposing a new four variable refined plate theory. Becheri et al. [32] presented exact analytical solution of buckling analysis of symmetrically cross-ply laminated plates subject to biaxial in-plane loads. Rajanna et al. [33] examined the effect of tension and compression buckling of cross-ply and angle-ply plates with circular and square cutouts subject to biaxial in-plane varying edge loads by Finite Element Method. Belkacem et al. [34] studied buckling behavior of hybrid (carbon/glass) laminated cross-ply plates under different boundary conditions, taking account the shear effect. Topal et al. [35] focused on the maximization of the critical buckling load of angle-ply plates resting on elastic foundation subjected to compressive loads using teaching learning based optimization method (TLBO) based on the governing equations of the first order shear deformation theory. Bourada et al. [36] have investigated buckling behavior of rectangular isotropic plates under uniaxial and biaxial compression by analyzing by the first order shear deformation theory. Fellah et al. [37] have presented a novel refined shear deformation theory for the buckling analysis of thick isotropic plates. Altekin [38, 39] has investigated bending, free vibration and buckling of super-elliptical plates. 
In view of the literature, the majority of the articles are concerned with critical buckling loads of mainly orthotropic rectangular plates (such as cross-ply laminates) with different theories and methods. Recently, Altunsaray and Bayer [40] investigated buckling analysis of symmetrically laminated quasi-isotropic thin rectangular plates subject to uniaxial compressive loading by Galerkin Method and Finite Difference Method based on Classical Laminated Plate Theory. The authors also used Finite Element Method software package ANSYS to compare the results. The importance of using the symmetrically laminated quasiisotropic plates which are constructed with $-45^{\circ},+45^{\circ}, 0^{\circ}$ and $90^{\circ}$ orientations used in engineering applications was indicated in the study of Altunsaray and Bayer [40]. An advantage of the symmetric laminate is that the bending-extension coupling matrix $\left(\mathrm{B}_{\mathrm{ij}}\right)$ is zero. Thus, symmetrically laminated plates are preferred in production because such plates remain flat after curing due to thermal strains encountered during the curing process. To the best knowledge of the authors, no comparative parametric study has been done on the biaxial buckling analysis of symmetrically laminated quasi-isotropic, cross-ply and angle-ply thin plates by using Rayleigh-Ritz method and FEM in the literature. The motivation of this paper is to study the buckling analysis of symmetrically laminated quasi-isotropic, cross-ply and angle-ply thin rectangular plates under biaxial compressive load and to estimate the influence of lamination types, aspect ratio and plate thickness on these types of plates. The plates are analyzed as they are subjected to simply supported boundary condition at the edge. Rayleigh Ritz method is used for the solution of integral equations based on the Classical Laminated Plate Theory. Finite Element Method software package ANSYS is used to compare the results.

\section{ANALYSIS}

\subsection{Geometry of plates, material properties and lamination types}

Positive rotation of principle material with local and global axes is given by Figure 1 .

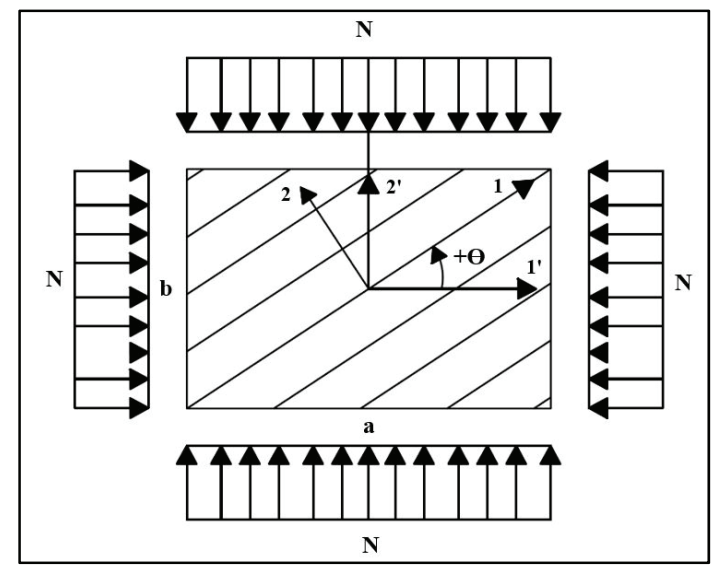

Figure 1 - Positive Rotation of Principal Material Axes from 1'-2' Axes (1-2 local axes, 1'2' global axes) 
Material properties of the carbon/epoxy composite, selected aspect ratios, lamination types and bending stiffness matrix are given in Tables 1, 2, 3 and 4, respectively. All laminated plates are symmetric, Quasi-isotropic plates have four different sequences $\left(-45^{\circ}, 0^{\circ}, 45^{\circ}\right.$ and $\left.90^{\circ}\right)$, Cross-ply laminated plates consist of two different sequences $\left(0^{\circ}\right.$ and $\left.90^{\circ}\right)$ and Angleply laminates have two different sequences $\left(-45^{\circ}\right.$ and $\left.45^{\circ}\right)$. Thickness of each lamina $(\mathrm{t})$ is equal to $0.2 \mathrm{~mm}$ thus the total thickness of a laminated plate is equal to $3.2 \mathrm{~mm}$.

Table 1 - Material properties of carbon/epoxy (T300-934) [41]

\begin{tabular}{|l|l|}
\hline Longitudinal Young Modulus $\left(\mathrm{E}_{11}\right)$ & $148 \times 10^{9}\left(\mathrm{~N} / \mathrm{m}^{2}\right)$ \\
\hline Transversal Young Modulus $\left(\mathrm{E}_{22}\right)$ & $9.65 \times 10^{9}\left(\mathrm{~N} / \mathrm{m}^{2}\right)$ \\
\hline Longitudinal Shear Modulus $\left(\mathrm{G}_{12}\right)$ & $4.55 \times 10^{9}\left(\mathrm{~N} / \mathrm{m}^{2}\right)$ \\
\hline Longitudinal Poisson ratio $\left(v_{12}\right)$ & 0.3 \\
\hline Lamina thickness $(\mathrm{t})$ & $0.185 \times 10^{-3}-0.213 \times 10^{-3}(\mathrm{~m})$ \\
\hline
\end{tabular}

Table 2 - Aspect ratios

\begin{tabular}{|l|l|l|l|l|l|l|}
\hline $\mathbf{a} / \mathbf{b}$ & 1 & 1.2 & 1.4 & 1.6 & 1.8 & 2 \\
\hline $\mathbf{b} / \mathbf{a}$ & 1 & 1.2 & 1.4 & 1.6 & 1.8 & 2 \\
\hline
\end{tabular}

Table 3 - Symmetrically laminated composite plate types

\begin{tabular}{|l|l|l|l|}
\hline LT1 & {$\left[-45_{2} / 0_{2} / 45_{2} / 90_{2}\right]_{\mathrm{s}}$} & $\mathbf{L T 1 5}$ & {$\left[45_{2} / 0_{2} /-45_{2} / 90_{2}\right]_{\mathrm{s}}$} \\
\hline LT2 & {$\left[-45_{2} / 0_{2} / 90_{2} / 45_{2}\right]_{\mathrm{s}}$} & LT16 & {$\left[45_{2} / 0_{2} / 90_{2} /-45_{2}\right]_{\mathrm{s}}$} \\
\hline LT3 & {$\left[-45_{2} / 45_{2} / 0_{2} / 90_{2}\right]_{\mathrm{s}}$} & LT17 & {$\left[45_{2} / 9_{02} /-45_{2} / 0_{2}\right]_{\mathrm{s}}$} \\
\hline LT4 & {$\left[-45_{2} / 45_{2} / 90_{2} / 0_{2}\right]_{\mathrm{s}}$} & LT18 & {$\left[45_{2} / 90_{2} / 0_{2} /-45_{2}\right]_{\mathrm{s}}$} \\
\hline LT5 & {$\left[-45_{2} / 90_{2} / 0_{2} / 45_{2}\right]_{\mathrm{s}}$} & LT19 & {$\left[90_{2} /-45_{2} / 0_{2} / 45_{2}\right]_{\mathrm{s}}$} \\
\hline LT6 & {$\left[-45_{2} / 90_{2} / 45_{2} / 0_{2}\right]_{\mathrm{s}}$} & LT20 & {$\left[90_{2} /-45_{2} / 45_{2} / 0_{2}\right]_{\mathrm{s}}$} \\
\hline LT7 & {$\left[0_{2} /-45_{2} / 45_{2} / 90_{2}\right]_{\mathrm{s}}$} & LT21 & {$\left[90_{2} / 0_{2} /-45_{2} / 45_{2}\right]_{\mathrm{s}}$} \\
\hline LT8 & {$\left[0_{2} /-45_{2} / 90_{2} / 45_{2}\right]_{\mathrm{s}}$} & LT22 & {$\left[90_{2} / 0_{2} / 45_{2} /-45_{2}\right]_{\mathrm{s}}$} \\
\hline LT9 & {$\left[0_{2} / 45_{2} /-45_{2} / 90_{2}\right]_{\mathrm{s}}$} & LT23 & {$\left[90_{2} / 45_{2} /-45_{2} / 0_{2}\right]_{\mathrm{s}}$} \\
\hline LT10 & {$\left[0_{2} / 45_{2} / 90_{2} /-45_{2}\right]_{\mathrm{s}}$} & LT24 & {$\left[90_{2} / 45_{2} / 0_{2} /-45_{2}\right]_{\mathrm{s}}$} \\
\hline LT11 & {$\left[0_{2} / 90_{2} /-45_{2} / 45_{2}\right]_{\mathrm{s}}$} & LT25 & {$\left[0_{2} / 90_{2} / 0_{2} / 90_{2}\right]_{\mathrm{s}}$} \\
\hline LT12 & {$\left[0_{2} / 90_{2} / 45_{2} /-45_{2}\right]_{\mathrm{s}}$} & LT26 & {$\left[90_{2} / 0_{2} / 90_{2} / 0_{2}\right]_{\mathrm{s}}$} \\
\hline LT13 & {$\left[45_{2} /-45_{2} / 0_{2} / 90_{2}\right]_{\mathrm{s}}$} & LT27 & {$\left[-45_{2} / 45_{2} /-45_{2} / 45_{2}\right]_{\mathrm{s}}$} \\
\hline LT14 & {$\left[45_{2} /-45_{2} / 90_{2} / 0_{2}\right]_{\mathrm{s}}$} & LT28 & {$\left[45_{2} /-45_{2} / 45_{2} /-45_{2}\right]_{\mathrm{s}}$} \\
\hline
\end{tabular}


When the laminate is symmetrical with respect to the mid-plane, it is referred to be a symmetrical laminate. Notation of the layup in LT1 $\left[-45_{2} / 02 / 45_{2} / 90_{2}\right]_{\text {s }}$ plate is given by Figure 2.

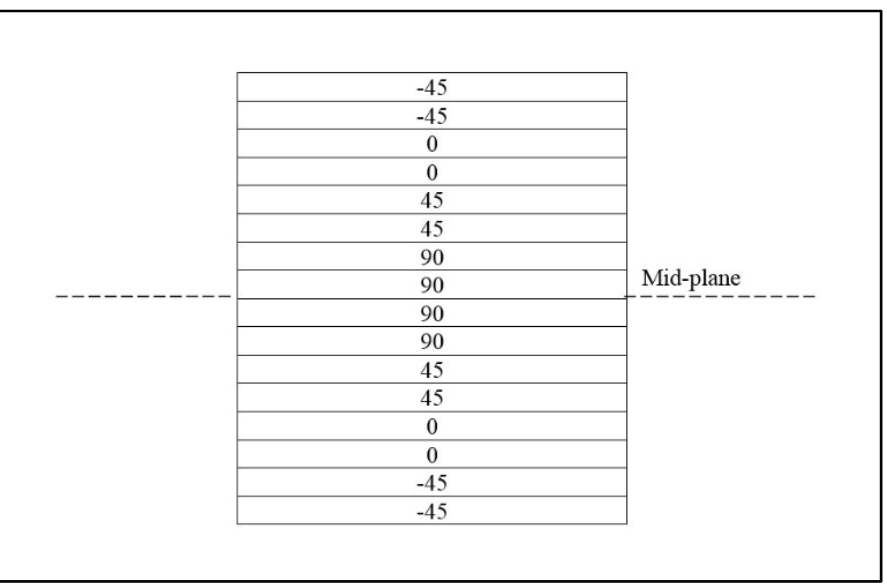

Figure 2 - Notation of the layup in LT1 $\left[-45_{2} / 0_{2} / 45_{2} / 90_{2}\right]_{\mathrm{s}}$ plate

Table 4 - Bending stiffness matrix of isotropic and symmetrically laminated plate types

\begin{tabular}{|c|c|c|}
\hline Plate Types & $\begin{array}{l}\text { Bending Stiffness } \\
\text { Matrix }\end{array}$ & Explanations \\
\hline Isotropic (single isotropic layer) & {$\left[\begin{array}{ccc}D & v D & 0 \\
v D & D & 0 \\
0 & 0 & \frac{(1-v)}{2} D\end{array}\right.$} & $\left(D_{11}=D_{22}=D\right)$ \\
\hline $\begin{array}{c}\text { Symmetrical Orthotropic (Cross-Ply) } \\
\text { Example: } \mathrm{LT} 25=\left[0_{2} / 90_{2} / 0_{2} / 90_{2}\right]_{\mathrm{s}}, \\
\text { LT26 }=\left[90_{2} / 0_{2} / 90_{2} / 0_{2}\right]_{\mathrm{s}}\end{array}$ & {$\left[\begin{array}{ccc}D_{11} & D_{12} & 0 \\
D_{12} & D_{22} & 0 \\
0 & 0 & D_{66}\end{array}\right]$} & $\left(D_{16}=D_{26}=0\right)$ \\
\hline $\begin{array}{l}\text { Symmetrical Angle-ply } \\
\text { Example: LT27 }=\left[-45_{2} / 45_{2} /-45_{2} / 45_{2}\right]_{\mathrm{s}} \\
\qquad \text { LT2 } 8=\left[45_{2} /-45_{2} / 45_{2} /-45_{2}\right]_{\mathrm{s}}\end{array}$ & {$\left[\begin{array}{lll}D_{11} & D_{12} & D_{16} \\
D_{12} & D_{22} & D_{26} \\
D_{16} & D_{26} & D_{66}\end{array}\right]$} & $\begin{array}{l}\left(D_{11}=D_{22}, D_{16}=\right. \\
\left.D_{26}\right)\end{array}$ \\
\hline $\begin{array}{l}\text { Symmetrical Quasi-isotropic } \\
\text { Example: LT1 }=\left[-45_{2} / 0_{2} / 45_{2} / 90_{2}\right]_{\mathrm{s}}\end{array}$ & {$\left[\begin{array}{lll}D_{11} & D_{12} & D_{16} \\
D_{12} & D_{22} & D_{26} \\
D_{16} & D_{26} & D_{66}\end{array}\right]$} & $\left(D_{16}=D_{26}\right)$ \\
\hline
\end{tabular}


Bending stiffness matrix of isotropic and symmetrically laminated plate types are given in Table 4. It can be seen from the Table 4, bend-twist coupling terms are equal zero $\left(D_{16}=D_{26}=0\right)$ for Isotropic and Cross-Ply plates, while these terms are different from zero for Angle-ply and Quasi-isotropic plates. Bending stiffness matrix elements $\left(D_{11}=D_{22}\right)$ of Angle-ply plates are similar to isotropic plates. Explanations are given in Section 3.1 in detail.

\subsection{Approximate solution methods in stability analysis of plates}

Exact analytical solutions for certain geometries and boundary conditions are possible with methods such as Navier or Levy. Approximate solution methods such as Galerkin Method, which is one of the weighted residual methods, Rayleigh-Ritz Method which is one of the variational methods and Finite Element Method is one of the powerful numerical solution techniques can be used for different situations.

The mathematical model in the differential equation form can be solved by the Galerkin method, while the model in the form of integral equation can be solved by the Rayleigh-Ritz method. When the same trial function is used, the results obtained by Rayleigh-Ritz and Galerkin Method are identical.

The Rayleigh-Ritz method is based on the principle of minimum potential energy. An approximate trial function that satisfies the geometric boundary conditions of the system is selected and placed in the total potential energy equation. Then, the total potential energy is minimized with respect to the unknown coefficients of the approximate trial function, which gives a linear homogenous equation system. The determinant of the coefficient matrix should be equal to zero for a non-trivial solution, which leads to a characteristic equation involving a polynomial. Finally, the lowest critical buckling load may be found by the smallest root of this equation.

Galerkin method is another form of the Ritz Method. For the Galerkin method, the governing differential equation for the problem is needed. First, an approximate deflection function including unknown coefficients and shape functions is chosen. When the selected approximate deflection function is placed into the governing differential equation, there will be a remaining part different from zero which is called 'residual'. The Galerkin method minimizes the sum of the product of this residual by the shape functions over the entire region of the problem. The rest of the problem will be similar to R-R method mentioned above [42].

In the Finite Element Method, the system is divided into a finite number of elements (meshing). Each of the elements that make up the system is called a finite element and the corner points where they join are called nodal points. The deformation of the finite element surface is expressed depending on the displacement parameters (displacement components, displacement vectors such as displacement components, rotations and torsional curves). Thousands of nodes are often needed to achieve a reasonably accurate solution, so using a computer is inevitable. In general, the accuracy of the solution increases as the number of elements (and nodes) increases at the expense of calculation time [43,44].

In this parametric study, the Rayleigh-Ritz Method, an energy method which is one of the approximate solution methods, and ANSYS [45] software based on Finite Element Method developed since 1969 were used. 


\subsubsection{Isotropic Plate Case and Applying of the Rayleigh-Ritz Method}

According to energy approach the strain energy of isotropic plate is given below [46]

$U=\frac{1}{2} \int_{0}^{a} \int_{0}^{b}\left[D\left(\left(\frac{\partial^{2} w}{\partial x^{2}}+\frac{\partial^{2} w}{\partial y^{2}}\right)^{2}-2(1-v)\left(\left(\frac{\partial^{2} w}{\partial x^{2}}\right)\left(\frac{\partial^{2} w}{\partial y^{2}}\right)\left(\frac{\partial^{2} w}{\partial x \partial y}\right)^{2}\right)\right)\right] d x d y$

Potential energy of the plate due to $\mathrm{N}_{\mathrm{x}}$ and $\mathrm{N}_{\mathrm{y}}$

$V=-\frac{1}{2} \int_{0}^{a} \int_{0}^{b}\left[N_{x}\left(\frac{\partial w}{\partial x}\right)^{2}+N_{y}\left(\frac{\partial w}{\partial y}\right)^{2}\right] d x d y$

$N_{x}=\gamma N_{y}$

where $\gamma=0$ for uniaxial loading and $\gamma=1$ for bi-axial compressive loading $\left(N_{x}=N_{y}\right)$. For this study $\gamma=1$ is assumed and hence:

$V=-\frac{1}{2} \int_{0}^{a} \int_{0}^{b} N\left(\left(\frac{\partial w}{\partial x}\right)^{2}+\left(\frac{\partial w}{\partial y}\right)^{2}\right) d x d y$

The potential energy functional is given below

$\mathrm{F}=\mathrm{U}+\mathrm{V}$

Substituting Eq. 1 and Eq. 4 into Eq. 5, the total potential energy is

$$
\begin{aligned}
& F=\frac{1}{2} \int_{0}^{a} \int_{0}^{b}\left[D\left(\left(\frac{\partial^{2} w}{\partial x^{2}}+\frac{\partial^{2} w}{\partial y^{2}}\right)^{2}-2(1-v)\left(\left(\frac{\partial^{2} w}{\partial x^{2}}\right)\left(\frac{\partial^{2} w}{\partial y^{2}}\right)\left(\frac{\partial^{2} w}{\partial x \partial y}\right)^{2}\right)\right)\right] d x d y \\
& -\frac{1}{2} \int_{0}^{a} \int_{0}^{b} N\left(\left(\frac{\partial w}{\partial x}\right)^{2}+\left(\frac{\partial w}{\partial y}\right)^{2}\right) d x d y
\end{aligned}
$$

Boundary conditions at edges of the plate;

(i) Simply supported; as the edges are free to rotate, the moment $M_{x}$ or $M_{y}$ must be zero,

$$
\begin{aligned}
& w=M_{x}=\frac{\partial^{2} w}{\partial x^{2}}=0 \text { at } \mathrm{x}=0 \text { and } \mathrm{x}=\mathrm{a} \\
& w=M_{y}=\frac{\partial^{2} w}{\partial y^{2}}=0 \text { at } \mathrm{y}=0 \text { and } \mathrm{y}=\mathrm{b}
\end{aligned}
$$

(ii) Clamped edges; as the edges cannot rotate, the first derivative of $\mathrm{w}$ with respect to $\mathrm{x}$ and y must be zero,

$w=\frac{\partial w}{\partial x}=0$ at $\mathrm{x}=0$ and $\mathrm{x}=\mathrm{a}$ 
$w=\frac{\partial w}{\partial y}=0$ at $\mathrm{y}=0$ and $\mathrm{y}=\mathrm{b}$

Deflection function which satisfies the boundary conditions is given below;

$\phi_{m n}=X m . Y n=\sin \left(\frac{m \pi x}{a}\right) \sin \left(\frac{n \pi y}{b}\right) \quad$ (for all edges simply supported)

$\phi_{m n}=X m . Y n=x^{2 m}(a-x)^{2 m} y^{2 n}(b-y)^{2 n} \quad($ for all edges clamped $)$

$w(x, y)=\sum_{m=1}^{M} \sum_{n=1}^{N} C_{m n} \phi_{m n}$

In order to find the lowest set of critical buckling loads, Equation (6) is minimized with respect to the coefficients $C_{m n}$

$\frac{\partial F}{\partial C_{m n}}=0$

Then, the following equation is obtained:

$\left[K-\lambda_{b} M_{b}\right]\left\{C_{m n}\right\}=0$

where $\lambda_{b}$ is the buckling load parameter including material properties, characteristic dimensions and in-plane uniform load of the plate. $\mathbf{K}$ is the stiffness matrix related with the strain energy and $M_{b}$ is the mass matrix related to potential energy. This is a generalized eigenvalue problem. For a non-trivial solution, the determinant of the coefficient matrix should be equal to zero:

$\left|K-\lambda_{b} M_{b}\right|=0$

Solution of equation (16) leads to a characteristic equation involving a polynomial, whose degree depends on the number of the terms of the deflection function, in $\lambda_{b}$, from which the lowest critical buckling loads $\left(\mathrm{N}_{\mathrm{cr}}\right)$ may be found.

\subsubsection{Symmetrically Laminated Composite Plate Cases and Applying of the Rayleigh- Ritz Method}

In this study buckling of symmetrically laminated Cross-Ply, Angle-Ply and Quasi-Isotropic thin plates were investigated based on the Classical Laminated Plate Theory (CLPT).

The strain energy $(U)$ of the symmetrically laminated plate is given by the following [47]:

$U=\frac{1}{2} \int_{0}^{a} \int_{0}^{b}\left[\begin{array}{c}D_{11}\left(\frac{\partial^{2} w}{\partial x^{2}}\right)^{2}+2 D_{12}\left(\frac{\partial^{2} w}{\partial x^{2}}\right)\left(\frac{\partial^{2} w}{\partial y^{2}}\right)+D_{22}\left(\frac{\partial^{2} w}{\partial y^{2}}\right)^{2} \\ +4 D_{16}\left(\frac{\partial^{2} w}{\partial x^{2}}\right)\left(\frac{\partial^{2} w}{\partial x \partial y}\right)+4 D_{26}\left(\frac{\partial^{2} w}{\partial y^{2}}\right)\left(\frac{\partial^{2} w}{\partial x \partial y}\right)+4 D_{66}\left(\frac{\partial^{2} w}{\partial x \partial y}\right)^{2}\end{array}\right] d x d y$ 
Where $\mathrm{D}_{11}, \mathrm{D}_{12}, \mathrm{D}_{22}, \mathrm{D}_{16}, \mathrm{D}_{26}$ and $\mathrm{D}_{66}$ indicate the elements of bending stiffness matrix $\mathrm{D}_{\mathrm{ij}}$ which are found by the following [47]:

$D_{i j}=\frac{1}{3} \sum_{k=1}^{n} \bar{Q}_{i j}^{k}\left(z_{k+1}^{3}-z_{k}^{3}\right)$

Where, $\overline{Q_{i j}}, \mathrm{n}, \mathrm{z}_{\mathrm{k}}$ and $\mathrm{z}_{\mathrm{k}-1}$ indicate the transformed reduced stiffness matrix, total number of plies and distance from the reference plane respectively [47]. The components of transformed reduced stiffness matrix, $\overline{Q_{i j}}$, calculated for each lamina is:

$\bar{Q}_{11}=Q_{11} c^{4}+2\left(Q_{12}+2 Q_{66}\right) s^{2} c^{2}+Q_{22} s^{4}$

$\bar{Q}_{12}=\left(Q_{11}+Q_{22}-4 Q_{66}\right) s^{2} c^{2}+Q_{12}\left(s^{4}+c^{4}\right)$

$\bar{Q}_{22}=Q_{11} s^{4}+2\left(Q_{12}+2 Q_{66}\right) s^{2} c^{2}+Q_{22} c^{4}$

$\bar{Q}_{16}=\left(Q_{11}-Q_{12}-2 Q_{66}\right) s c^{3}+\left(Q_{12}-Q_{22}+2 Q_{66}\right) s^{3} c$

$\bar{Q}_{26}=\left(Q_{11}-Q_{12}-2 Q_{66}\right) s^{3} c+\left(Q_{12}-Q_{22}+2 Q_{66}\right) s c^{3}$

$\bar{Q}_{66}=\left(Q_{11}+Q_{22}-2 Q_{12}-2 Q_{66}\right) s^{2} c^{2}+Q_{66}\left(s^{4}+c^{4}\right)$

Where $\mathrm{c}=\cos (\theta)$ and $\mathrm{s}=\sin (\theta)$ respectively. The reduced stiffness matrix elements, $\mathrm{Q}_{\mathrm{ij}}$, are given below:

$Q_{11}=\frac{E_{11}}{1-v_{12} v_{21}}$

$Q_{12}=\frac{v_{12} E_{11}}{1-v_{12} v_{21}}$

$Q_{22}=\frac{E_{22}}{1-v_{12} v_{21}}$,

$Q_{66}=G_{12}$

For symmetrically laminated composite plate cases, only the simply supported boundary condition at the all four edges of plates is considered. Then the lowest critical buckling loads $\left(\mathrm{N}_{\mathrm{cr}}\right)$ can be found as applying the same procedure as the isotropic case in Section 2.2.1.

\subsubsection{Finite Element Method (FEM) software package ANSYS}

In this study, in order to compare the results obtained by Rayleigh-Ritz Method, Finite Element Method software ANSYS was used and the numerical results were given in Table 11,12 and 13. It can be seen that the results of the two methods are correlated. Then, the nondimensional results calculated by Rayleigh-Ritz Method and are presented in Table 14 and 15 to give practical data for designers.

A four nodal point shell element (SHELL 181) with six degrees of freedom at each node (see Figure 3) was used in finite element software package ANSYS [45]. SHELL181 element, 
which is capable of modeling up to 250 plies, was selected for layered applications. The accuracy in modeling composite shells is governed by the first-order shear-deformation theory [45].

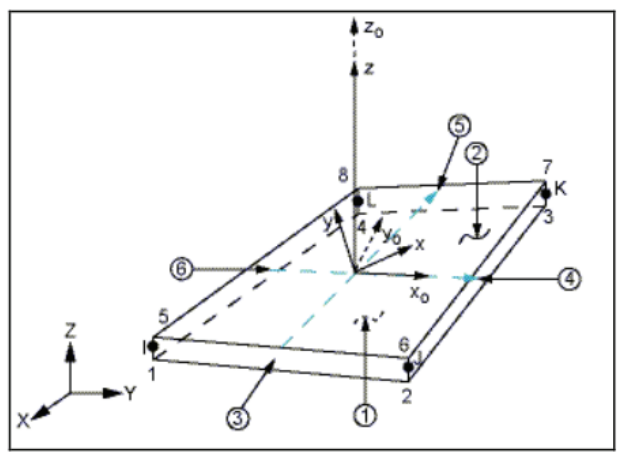

Figure 3 - Four nodal point rectangular shell element SHELL181 (ANSYS, 2019)

For meshing geometry, the rectangular element size was taken as $0.01 \mathrm{~m}$. x $0.01 \mathrm{~m}$. (Small edge of plate / Length of SHELL181 finite element=20). There are 400 elements in square plates $(\mathrm{a} / \mathrm{b}=\mathrm{b} / \mathrm{a}=1)$ and 800 elements in rectangular plates $(\mathrm{a} / \mathrm{b}=\mathrm{b} / \mathrm{a}=2)$. Convergence study with the number of finite elements is given in Table 5. The ratio of "Small edge of plate / Length of SHELL181 finite element" was taken to be 20 in order to obtain good convergence and high accuracy with low computational time.

Table 5 - Convergence study with increasing number of finite elements for LT1 $\left[-45_{2} / 0_{2} / 45_{2} / 90_{2}\right]_{\text {s }}$ plate

\begin{tabular}{|c|c|c|c|c|c|c|c|}
\hline & \multicolumn{7}{|c|}{ Critical buckling load Ncr (N/m) } \\
\cline { 2 - 8 } & \multicolumn{7}{|c|}{ Small edge of plate / Length of SHELL181 finite element } \\
\cline { 2 - 8 } & $\mathbf{2}$ & $\mathbf{4}$ & $\mathbf{8}$ & $\mathbf{1 0}$ & $\mathbf{2 0}$ & $\mathbf{4 0}$ & $\mathbf{5 0}$ \\
\hline $\mathbf{a} / \mathbf{b}$ & $\mathrm{Ncr}(\mathrm{N} / \mathrm{m})$ & $\mathrm{Ncr}(\mathrm{N} / \mathrm{m})$ & $\mathrm{Ncr}(\mathrm{N} / \mathrm{m})$ & $\mathrm{Ncr}(\mathrm{N} / \mathrm{m})$ & Ncr $(\mathbf{N} / \mathbf{m})$ & $\mathrm{Ncr}(\mathrm{N} / \mathrm{m})$ & $\mathrm{Ncr}(\mathrm{N} / \mathrm{m})$ \\
\hline $\mathbf{1}$ & 150604 & 93301 & 84726 & 83781 & $\mathbf{8 2 5 3 7}$ & 82224 & 82186 \\
\hline $\mathbf{2}$ & 58495 & 42770 & 40016 & 39706 & $\mathbf{3 9 2 9 7}$ & 39194 & 39181 \\
\hline
\end{tabular}

\section{RESULTS}

\subsection{Isotropic plate case}

A convergence study was done for the all edges simply supported case of isotropic plates. The results obtained by R-R method were compared with the results given in [48]. It can be seen from Table 6 that a convergence is observed after the 2nd terms (Table 5).

The critical buckling load equation obtained for the bi-axial buckling condition is given below [48]: 
$N_{c r}=\frac{\pi^{2} D}{b^{2}}\left[1+\left(\frac{b}{a}\right)^{2}\right]$

The critical buckling load for isotropic plates may be found by equation (22). It can be noticed that when the aspect ratios $a / b=b / a$, the results will be equal . However, the situation is different in symmetrically laminated composite plates, which can be seen from the critical buckling load equation presented in Table 10.

$N_{c r}=\frac{b^{4} D_{11} \pi^{2}+2 a^{2} b^{2} D_{12} \pi^{2}+a^{4} D_{22} \pi^{2}+4 a^{2} b^{2} D_{66} \pi^{2}}{a^{2} b^{2}\left(a^{2}+b^{2}\right)}$

In this equation, while the coefficient of $a^{4}$ is $D_{22}$, and that of $b^{4}$ is $D_{11}$. Elements of bending stiffness matrix $\mathrm{D}_{11}$ and $\mathrm{D}_{22}$ are not equal for Cross-Ply laminated plates (LT25 and LT26) and Quasi-isotropic laminated plates (LT1-LT24) except Angle-Ply laminated plates (LT27 and LT28) in Table 8. Hence, if only $\mathrm{a}=\mathrm{b}$, the $\mathrm{N}_{\mathrm{cr}}$ (Equation.22) gives the same result, and the results for the different edge ratios of $a$ and $b$ are different for symmetrically laminated composite plate cases (Cross-Ply and Quasi-isotropic plates).

A comparison for the clamped case was not achieved for isotropic plates, because no results were found for this particular case in the literature, so no results were obtained by ANSYS software either. However, a convergence is observed in this present study for the all edges clamped case, which can be observed after the 3rd term (Table 7).

For the deflection function, a trigonometric trial function for the simply supported condition was selected, while an algebraic polynomial trial function given in Section 2.2.1 was selected for the clamped support condition.

$$
\begin{aligned}
& \phi_{m n}=X m \cdot Y n=\sin \left(\frac{m \pi x}{a}\right) \sin \left(\frac{n \pi y}{b}\right) \\
& \phi_{m n}=X m . Y n=x^{2 m}(a-x)^{2 m} y^{2 n}(b-y)^{2 n}
\end{aligned}
$$

Table 6 - Convergence study of isotropic plates with all edges are simply supported

\begin{tabular}{|c|c|c|c|c|c|}
\hline \multicolumn{5}{|c|}{ Critical buckling load Ncr } \\
\hline \multirow{2}{*}{$\mathbf{a} / \mathbf{b}$} & \multirow{2}{*}{$\begin{array}{l}\text { Kentsel and } \\
\text { Krauthammer,2001 }\end{array}$} & \multicolumn{4}{|c|}{ Present (Rayleigh-Ritz) } \\
\cline { 3 - 6 } & $19,7392 \mathrm{D}$ & $20,8000 \mathrm{D}$ & $19,7392 \mathrm{D}$ & $19,7392 \mathrm{D}$ & $19,7392 \mathrm{D}$ \\
\hline $\mathbf{1}$ & $16,7235 \mathrm{D}$ & $17,9308 \mathrm{D}$ & $16,7235 \mathrm{D}$ & $16,7235 \mathrm{D}$ & $16,7235 \mathrm{D}$ \\
\hline $\mathbf{1 , 2}$ & $14,9051 \mathrm{D}$ & $16,5957 \mathrm{D}$ & $14,9051 \mathrm{D}$ & $14,9051 \mathrm{D}$ & $14,9051 \mathrm{D}$ \\
\hline $\mathbf{1 , 4}$ & $13,7249 \mathrm{D}$ & $15,9579 \mathrm{D}$ & $13,7249 \mathrm{D}$ & $13,7249 \mathrm{D}$ & $13,7249 \mathrm{D}$ \\
\hline $\mathbf{1 , 6}$ & $12,9158 \mathrm{D}$ & $15,6553 \mathrm{D}$ & $12,9158 \mathrm{D}$ & $12,9158 \mathrm{D}$ & $12,9158 \mathrm{D}$ \\
\hline $\mathbf{1 , 8}$ & $12,3370 \mathrm{D}$ & $15,5200 \mathrm{D}$ & $12,3370 \mathrm{D}$ & $12,3370 \mathrm{D}$ & $12,3370 \mathrm{D}$ \\
\hline $\mathbf{2}$ & & & & & \\
\hline
\end{tabular}


For the simply supported case of isotropic plates, even though the $m$ and $n$ values increase, the results remain the same after $2^{\text {nd }}$ term. It is thought that it may be as a result of the trigonometric shape function which is widely used in the literature. The same situation is observed in the convergence analysis results given in Table 9 for symmetrically laminated composite plates.

Table 7 - Convergence study of isotropic plates with all edges are clamped

\begin{tabular}{|c|c|c|c|c|}
\hline \multicolumn{5}{|c|}{ Critical buckling load Ncr } \\
\hline \multirow{2}{*}{$\mathbf{a} / \mathbf{b}$} & $\mathbf{1}$ term & $\mathbf{2}$ terms & $\mathbf{3}$ terms & 4 terms \\
\cline { 2 - 5 } $\mathbf{1}$ & $54,0000 \mathrm{D}$ & $53,2226 \mathrm{D}$ & $52,5145 \mathrm{D}$ & $52,5145 \mathrm{D}$ \\
\hline $\mathbf{1 , 2}$ & $46,5765 \mathrm{D}$ & $46,0815 \mathrm{D}$ & $45,2341 \mathrm{D}$ & $45,2341 \mathrm{D}$ \\
\hline $\mathbf{1 , 4}$ & $43,1583 \mathrm{D}$ & $42,7891 \mathrm{D}$ & $41,7908 \mathrm{D}$ & $41,7908 \mathrm{D}$ \\
\hline $\mathbf{1 , 6}$ & $41,5523 \mathrm{D}$ & $41,2406 \mathrm{D}$ & $40,0979 \mathrm{D}$ & $40,0979 \mathrm{D}$ \\
\hline $\mathbf{1 , 8}$ & $40,8120 \mathrm{D}$ & $40,5229 \mathrm{D}$ & $39,2512 \mathrm{D}$ & $39,2512 \mathrm{D}$ \\
\hline $\mathbf{2}$ & $40,5000 \mathrm{D}$ & $40,2112 \mathrm{D}$ & $38,8304 \mathrm{D}$ & $38,8304 \mathrm{D}$ \\
\hline
\end{tabular}

\subsection{Symmetrically laminated composite plates cases}

\subsubsection{Elements of bending stiffness matrix of lamination types}

Elements of bending stiffness matrix of 28 different lamination types calculated by CLPT given are in Table 8.

Table 8 -Elements of bending stiffness matrix of 28 different lamination types

\begin{tabular}{|c|c|c|c|c|c|c|}
\hline & $\mathbf{D}_{\mathbf{1 1}}$ (N.m) & $\mathbf{D}_{\mathbf{1 2}}$ (N.m) & $\mathbf{D}_{\mathbf{1 6}}$ (N.m) & $\mathbf{D}_{\mathbf{2 2}}$ (N.m) & $\mathbf{D}_{\mathbf{2 6}}$ (N.m) & $\mathbf{D}_{\mathbf{6 6}}$ (N.m) \\
\hline LT1 & 206,80 & 71,10 & $-44,53$ & 99,92 & $-44,53$ & 75,58 \\
\hline LT2 & 197,60 & 62,49 & $-53,44$ & 126,35 & $-53,44$ & 66,96 \\
\hline LT3 & 153,95 & 88,33 & $-26,72$ & 118,33 & $-26,72$ & 92,80 \\
\hline LT4 & 118,33 & 88,33 & $-26,72$ & 153,95 & $-26,72$ & 92,80 \\
\hline LT5 & 126,35 & 62,49 & $-53,44$ & 197,60 & $-53,44$ & 66,96 \\
\hline LT6 & 99,92 & 71,10 & $-44,53$ & 206,80 & $-44,53$ & 75,58 \\
\hline LT7 & 286,08 & 45,27 & $-17,81$ & 72,32 & $-17,81$ & 49,74 \\
\hline LT8 & 276,88 & 36,66 & $-26,72$ & 98,74 & $-26,72$ & 41,13 \\
\hline LT9 & 286,08 & 45,27 & 17,81 & 72,32 & 17,81 & 49,74 \\
\hline
\end{tabular}


Table 8 -Elements of bending stiffness matrix of 28 different lamination types (continue)

\begin{tabular}{|c|c|c|c|c|c|c|}
\hline & $\mathbf{D}_{11}$ (N.m) & $\mathbf{D}_{12}$ (N.m) & $\mathbf{D}_{16}$ (N.m) & $\mathbf{D}_{22}$ (N.m) & $\mathbf{D}_{26}$ (N.m) & $\mathbf{D}_{66}$ (N.m) \\
\hline LT10 & 276,88 & 36,66 & 26,72 & 98,74 & 26,72 & 41,13 \\
\hline LT11 & 258,47 & 19,43 & $-8,91$ & 151,59 & $-8,91$ & 23,91 \\
\hline LT12 & 258,47 & 19,43 & 8,91 & 151,59 & 8,91 & 23,91 \\
\hline LT13 & 153,95 & 88,33 & 26,72 & 118,33 & 26,72 & 92,80 \\
\hline LT14 & 118,33 & 88,33 & 26,72 & 153,95 & 26,72 & 92,80 \\
\hline LT15 & 206,80 & 71,10 & 44,53 & 99,92 & 44,53 & 75,58 \\
\hline LT16 & 197,60 & 62,49 & 53,44 & 126,35 & 53,44 & 66,96 \\
\hline LT17 & 99,92 & 71,10 & 44,53 & 206,80 & 44,53 & 75,58 \\
\hline LT18 & 126,35 & 62,49 & 53,44 & 197,60 & 53,44 & 66,96 \\
\hline LT19 & 98,74 & 36,66 & $-26,72$ & 276,88 & $-26,72$ & 41,13 \\
\hline LT20 & 72,32 & 45,27 & $-17,81$ & 286,08 & $-17,81$ & 49,74 \\
\hline LT21 & 151,59 & 19,43 & $-8,91$ & 258,47 & $-8,91$ & 23,91 \\
\hline LT22 & 151,59 & 19,43 & 8,91 & 258,47 & 8,91 & 23,91 \\
\hline LT23 & 72,32 & 45,27 & 17,81 & 286,08 & 17,81 & 49,74 \\
\hline LT24 & 98,74 & 36,66 & 26,72 & 276,88 & 26,72 & 41,13 \\
\hline LT25 & 287.7687 & 7.9519 & 0 & 145.2620 & 0 & 12.4245 \\
\hline LT26 & 145.2620 & 7.9519 & 0 & 287.7687 & 0 & 12.4245 \\
\hline LT27 & 124.6582 & 99.8091 & -35.6267 & 124.6582 & -35.6267 & 104.2817 \\
\hline LT28 & 124.6582 & 99.8091 & 35.6267 & 124.6582 & 35.6267 & 104.2817 \\
\hline
\end{tabular}

\subsubsection{Convergence study for composite plates}

For the study of the convergence of results, critical buckling load of LT1 ([- $\left.\left.45_{2} / 02 / 45_{2} / 90_{2}\right]_{\mathrm{s}}\right)$ a plate with simply supported boundary condition is investigated. The shape functions with increasing terms were employed in order to reach convergence and the results are given in Table 9. It can be noticed from Table 9 that the convergence achieved is sufficient, if a shape function with 4 terms is selected. Four-term solutions are of more economical computational time than those of six or nine terms. Additionally, another important reason for why calculation with 4 terms is preferred, as shown in Table 10, is that bending-twisting coupling terms $\mathrm{D}_{16}$ and $\mathrm{D}_{26}$ are not included in the calculation with 3 terms, while they are included in 4-term calculation. Thus, this shape function with four terms will be used for all calculations in the rest of the study. The effect of bending-twisting coupling terms $\mathrm{D}_{16}$ and $\mathrm{D}_{26}$ for critical 
Buckling Analysis of Symmetrically Laminated Rectangular Thin Plates Under ...

buckling loads of plates demonstrated in Table 11. From the results it seems that bendingtwisting coupling-terms decrease the critical buckling load.

Table 9 - Convergence study of LT1 plate for aspect ratio=a/b=1 ( Xm=sin(m.Pi.x/a), $\mathrm{Yn}=\sin (\mathrm{n} . \mathrm{Pi} . \mathrm{y} / \mathrm{b})$ )

\begin{tabular}{|c|c|c|c|}
\hline \multicolumn{2}{|c|}{ Critical buckling load Ncr (N/m) } \\
\hline \multirow{2}{*}{$\begin{array}{c}\mathbf{m} / \\
\mathbf{n}\end{array}$} & $\mathbf{1}$ & $\mathbf{2}$ & $\mathbf{3}$ \\
\hline $\mathbf{1}$ & $\mathbf{1}$ term & $\mathbf{2}$ terms & $\mathbf{3}$ terms \\
\cline { 2 - 4 } & $\mathrm{X} 1 . \mathrm{Y} 1$ & $\mathrm{X} 1 . \mathrm{Y} 1+\mathrm{X} 1 . \mathrm{Y} 2$ & $\mathrm{X} 1 . \mathrm{Y} 1+\mathrm{X} 1 . \mathrm{Y} 2+\mathrm{X} 1 . \mathrm{Y} 3$ \\
\cline { 2 - 4 } & 92680,5 & 92680,5 & 92680,5 \\
\hline \multirow{4}{*}{$\mathbf{2}$} & $\mathbf{2 ~ t e r m s}$ & $\mathbf{4}$ terms & $\mathbf{6}$ terms \\
\cline { 2 - 4 } & $\mathrm{X} 1 . \mathrm{Y} 1+\mathrm{X} 2 . \mathrm{Y} 1$ & $\mathrm{X} 1 . \mathrm{Y} 1+\mathrm{X} 2 . \mathrm{Y} 1+\mathrm{X} 2 . \mathrm{Y} 1+\mathrm{X} 2 . \mathrm{Y} 2$ & $\mathrm{X} 1 . \mathrm{Y} 1+\mathrm{X} 1 . \mathrm{Y} 2+\mathrm{X} 1 . \mathrm{Y} 3+\mathrm{X} 2 . \mathrm{Y} 1+\mathrm{X}$ \\
& & & $2 . \mathrm{Y} 2$ \\
\cline { 2 - 4 } & 92680,5 & 87154,6 & $+\mathrm{X} 2 . \mathrm{Y} 3$ \\
\hline \multirow{4}{*}{$\mathbf{3}$} & $\mathbf{3 ~ t e r m s}$ & $\mathbf{6}$ terms & 86848,6 \\
\cline { 2 - 4 } & $\mathrm{X} 1 . \mathrm{Y} 1+\mathrm{X} 2 . \mathrm{Y} 1$ & $\mathrm{X} 1 . \mathrm{Y} 1+\mathrm{X} 1 . \mathrm{Y} 2+\mathrm{X} 2 . \mathrm{Y} 1+\mathrm{X} 2 . \mathrm{Y} 2$ & $\mathrm{X} 1 . \mathrm{Y} 1+\mathrm{X} 2 . \mathrm{Y} 1+\mathrm{X} 3 . \mathrm{Y} 1+\mathrm{X} 2 . \mathrm{Y} 1+\mathrm{X}$ \\
& $+\mathrm{X} 3 . \mathrm{Y} 1$ & $+\mathrm{X} 3 . \mathrm{Y} 1$ & $2 . \mathrm{Y} 2$ \\
& & $+\mathrm{X} 3 . \mathrm{Y} 2$ & $+\mathrm{X} 3 . \mathrm{Y} 3+\mathrm{X} 3 . \mathrm{Y} 1+\mathrm{X} 3 . \mathrm{Y} 2+\mathrm{X} 3 . \mathrm{Y} 3$ \\
\cline { 2 - 4 } & 92680,5 & 87003,5 & 86286.9 \\
\hline
\end{tabular}

Table 10 - Comparison of three and four terms solution of critical buckling load of LT1 Plate

\begin{tabular}{|c|c|c|}
\hline Terms & Computations of critical buckling load Ner (N/m) by Mathematica & $\mathbf{a} / \mathbf{b}=\mathbf{1}$ \\
\hline 3 & $\left\{\left\{\mathrm{~N} \rightarrow \frac{\mathrm{b}^{4} \mathrm{D} 11 \pi^{2}+2 \mathrm{a}^{2} \mathrm{~b}^{2} \mathrm{D} 12 \pi^{2}+\mathrm{a}^{4} \mathrm{D} 22 \pi^{2}+4 \mathrm{a}^{2} \mathrm{~b}^{2} \mathrm{D} 66 \pi^{2}}{\mathrm{a}^{2} \mathrm{~b}^{2}\left(\mathrm{a}^{2}+\mathrm{b}^{2}\right)}\right\}\right.$ & 92680.5 \\
\hline 4 & 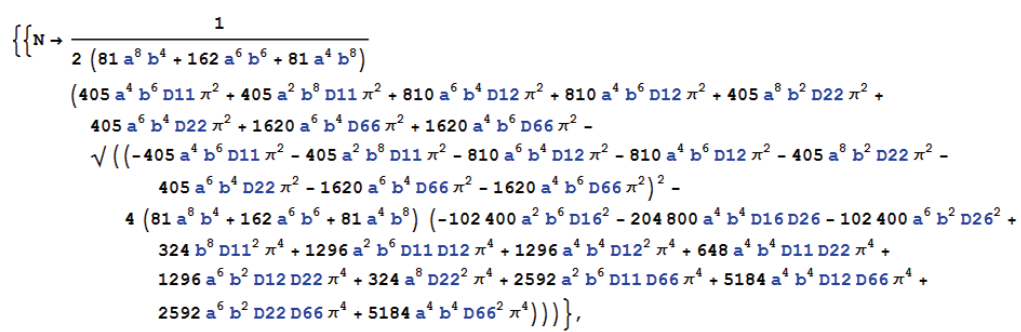 & 87154.6 \\
\hline
\end{tabular}


Table 11 - Effect of bending-twisting coupling terms $\left(D_{16}, D_{26}\right)$ for critical buckling load $\mathrm{Ncr}$

\begin{tabular}{|c|c|c|c|c|c|}
\hline \multirow{2}{*}{\multicolumn{4}{|c|}{4 terms solution $(a / b=1)$}} & \multicolumn{2}{|c|}{ Critical buckling load Ner (N/m) } \\
\hline & & & & \multirow{2}{*}{$\begin{array}{c}\text { with } D_{\mathbf{1 6}} \text { and } D_{\mathbf{2 6}} \text { terms } \\
61516\end{array}$} & \multirow{2}{*}{$\begin{array}{c}\begin{array}{c}\text { neglecting } D_{16} \text { and } D_{26} \\
\text { terms }\end{array} \\
\left(D_{16}=D_{\mathbf{2 6}}=\mathbf{0}\right)\end{array}$} \\
\hline & & LT25 & LT26 & & \\
\hline LT11 & LT12 & LT21 & LT22 & 66872 & 67183 \\
\hline LT8 & LT10 & LT19 & LT24 & 73224 & 75682 \\
\hline LT7 & LT9 & LT20 & LT23 & 78891 & 79932 \\
\hline LT2 & LT5 & LT16 & LT18 & 80182 & 88431 \\
\hline LT1 & LT6 & LT15 & LT17 & 87155 & 92681 \\
\hline \multirow[t]{2}{*}{ LT3 } & LT4 & LT13 & LT14 & 99333 & 101180 \\
\hline & & LT27 & LT28 & 103747 & 106846 \\
\hline
\end{tabular}

\subsubsection{Effect of thickness}

Critical buckling loads of symmetrically laminated rectangular plates for three different thicknesses $(3.2,4.8$ and $6.4 \mathrm{~mm})$ and six aspect ratios $(\mathrm{a} / \mathrm{b}$ and $\mathrm{b} / \mathrm{a})$ were investigated and the results are presented in Table 12. It can be seen from the results that the critical buckling loads increase with the increase of the plate thickness. It can be noticed from Table 12 that the critical buckling loads decrease with the increase of the aspect ratio. From the tabulated results, differences between the results of Rayleigh-Ritz and FEM (ANSYS) grow with the increases of the thickness. In this study, because thin plates $(\mathrm{t}=3.2 \mathrm{~mm})$ are studied, Classical Laminated Plate Theory (CLPT) is suitable. For thicker plates, shear deformable plate theories should be considered.

Table 12 - Critical buckling load $N_{c r}(\mathrm{~N} / \mathrm{m})$ of different thinner or thicker plates

\begin{tabular}{|c|c|c|c|c|c|c|}
\hline \multirow{4}{*}{$\begin{array}{l}\text { a/ } \\
\mathbf{b}\end{array}$} & \multicolumn{6}{|c|}{ Critical buckling load (N/m) } \\
\hline & \multicolumn{2}{|c|}{$\left[-45_{2} / 02 / 45_{2} / 90_{2}\right] \mathrm{s}$} & \multicolumn{2}{|c|}{$\left[-45_{3} / 0_{3} / 45_{3} / 90_{3}\right] \mathrm{s}$} & \multicolumn{2}{|c|}{$\left[-45_{4} / \mathbf{0}_{4} / 45_{4} / 90_{4}\right] \mathrm{s}$} \\
\hline & \multicolumn{2}{|c|}{$\mathrm{t}=3.2 \mathrm{~mm}$} & \multicolumn{2}{|c|}{$\mathrm{t}=4.8 \mathrm{~mm}$} & \multicolumn{2}{|c|}{$\mathrm{t}=6.4 \mathrm{~mm}$} \\
\hline & $\begin{array}{l}\text { Rayleigh- } \\
\text { Ritz }\end{array}$ & $\begin{array}{c}\text { FEM(ANSY } \\
\text { S) }\end{array}$ & $\begin{array}{l}\text { Rayleigh- } \\
\text { Ritz }\end{array}$ & $\begin{array}{c}\text { FEM(ANSY } \\
\text { S) }\end{array}$ & $\begin{array}{l}\text { Rayleigh- } \\
\text { Ritz }\end{array}$ & $\begin{array}{c}\text { FEM(ANSY } \\
\text { S) }\end{array}$ \\
\hline 1,0 & 87155 & 82537 & 291181 & 275262 & 698266 & 641889 \\
\hline 1,2 & 69227 & 65368 & 229920 & 218516 & 552296 & 511192 \\
\hline 1,4 & 57983 & 54732 & 191931 & 183233 & 461300 & 429522 \\
\hline 1,6 & 50452 & 47695 & 166710 & 159836 & 400630 & 375192 \\
\hline 1,8 & 45166 & 42812 & 149117 & 143575 & 358169 & 337350 \\
\hline 2,0 & 41321 & 39297 & 136371 & 131855 & 327330 & 310035 \\
\hline
\end{tabular}


Buckling Analysis of Symmetrically Laminated Rectangular Thin Plates Under ...

Table 12 - Critical buckling load $N_{c r}(\mathrm{~N} / \mathrm{m})$ of different thinner or thicker plates (continued)

\begin{tabular}{|c|c|c|c|c|c|c|}
\hline \multirow{4}{*}{$\begin{array}{l}\mathbf{b} / \\
\mathbf{a}\end{array}$} & \multicolumn{6}{|c|}{ Critical buckling load (N/m) } \\
\hline & \multirow{2}{*}{\multicolumn{2}{|c|}{$\frac{\left[-45_{2} / 0_{2} / 45_{2} / 90_{2}\right] \mathrm{s}}{t=3.2 \mathrm{~mm}}$}} & \multirow{2}{*}{\multicolumn{2}{|c|}{$\frac{\left[-45_{3} / 0_{3} / 45_{3} / 90_{3}\right] \mathrm{s}}{\mathrm{t}=4.8 \mathrm{~mm}}$}} & \multirow{2}{*}{\multicolumn{2}{|c|}{$\begin{array}{c}{\left[-45_{4} / 0_{4} / 45_{4} / 90_{4}\right] \mathrm{s}} \\
\mathrm{t}=6.4 \mathrm{~mm}\end{array}$}} \\
\hline & & & & & & \\
\hline & $\begin{array}{c}\text { Rayleigh- } \\
\text { Ritz }\end{array}$ & $\begin{array}{c}\text { FEM(ANSY } \\
\text { S) }\end{array}$ & $\begin{array}{c}\text { Rayleigh- } \\
\text { Ritz }\end{array}$ & $\begin{array}{c}\text { FEM(ANSY } \\
\text { S) } \\
\end{array}$ & $\begin{array}{c}\text { Rayleigh- } \\
\text { Ritz } \\
\end{array}$ & $\begin{array}{c}\text { FEM(ANSY } \\
\text { S) } \\
\end{array}$ \\
\hline 1,0 & 87155 & 82537 & 291181 & 275262 & 698266 & 641889 \\
\hline 1,2 & 77739 & 74110 & 261746 & 247476 & 626008 & 578097 \\
\hline 1,4 & 71597 & 68696 & 242862 & 229585 & 579251 & 536898 \\
\hline 1,6 & 67340 & 64981 & 229941 & 217290 & 547043 & 508527 \\
\hline 1,8 & 64265 & 62314 & 220689 & 208453 & 523866 & 488101 \\
\hline 2,0 & 61971 & 60332 & 213835 & 201882 & 506630 & 472898 \\
\hline
\end{tabular}

\subsubsection{Effect of lamination types and aspect ratios}

Symmetrically laminated composite rectangular thin plates (Quasi-isotropic plates, CrossPly plates and Angle-Ply plates) consisting of 28 different types shown in Table 3 are used for the calculations of critical buckling loads $\mathrm{N}_{\mathrm{cr}}(\mathrm{N} / \mathrm{m})$ of plates under simply supported boundary condition and the results are tabulated in Tables 13-14.

It is seen from the results that critical buckling loads depend on lamination types. Critical buckling loads increase with the decrease of the aspect ratios $(\mathrm{a} / \mathrm{b}$ or $\mathrm{b} / \mathrm{a})$.

It is seen from the Table 13 (short edge is on the y axis: a/b) Angle-ply plates LT27 ( [$\left.\left.45_{2} / 45_{2} /-45_{2} / 45_{2}\right]_{\mathrm{s}}\right)$ and LT28 ( $\left.\left[45_{2} /-45_{2} / 45_{2} /-45_{2}\right]_{\mathrm{s}}\right)$ have the highest value for the lowest critical buckling loads $(103747 \mathrm{~N} / \mathrm{m})$ for aspect ratio $\mathrm{a} / \mathrm{b}=1$. For aspect ratio $\mathrm{a} / \mathrm{b}=2$, both of the Quasi-isotropic plates LT20 $\left(\left[90_{2} /-45_{2} / 45_{2} / 0_{2}\right]_{\mathrm{s}}\right)$ and LT23 $\left(\left[90_{2} / 45_{2} /-45_{2} / 0_{2}\right]_{\mathrm{s}}\right)$ have the highest value for the lowest critical buckling loads $(71357 \mathrm{~N} / \mathrm{m})$.

It can be noticed from Table 14 (short edge is on the $\mathrm{x}$ axis: b/a), Angle-ply plates LT27 ( [$\left.\left.45_{2} / 45_{2} /-45_{2} / 45_{2}\right]_{\mathrm{s}}\right)$ and LT28 $\left(\left[45_{2} /-45_{2} / 45_{2} /-45_{2}\right]_{\mathrm{s}}\right)$ have the highest value for the lowest critical buckling loads $(103747 \mathrm{~N} / \mathrm{m})$ for aspect ratio $\mathrm{b} / \mathrm{a}=1$. For aspect ratio $\mathrm{b} / \mathrm{a}=2$, LT7 $\left(\left[00_{2} /-45_{2} / 45_{2} / 90_{2}\right]_{\mathrm{s}}\right)$ and LT9 $\left(\left[0 \mathrm{O}_{2} / 45_{2} /-45_{2} / 90_{2}\right]_{\mathrm{s}}\right)$ have the highest value for the lowest critical buckling loads $(71357 \mathrm{~N} / \mathrm{m})$.

Table 13 - Critical buckling load (N/m), short edge is on the y axis

\begin{tabular}{|c|c|c|c|c|c|c|c|c|c|c|c|}
\hline \multirow{3}{*}{$\mathbf{a} / \mathbf{b}$} & \multirow{3}{*}{ Method } & \multicolumn{10}{|c|}{ Plate Types } \\
\hline & & LT1 & L15 & LT2 & L16 & LT3 & LT13 & LT4 & LT14 & LT5 & LT18 \\
\hline & & \multicolumn{2}{|c|}{$\begin{array}{c}\mathbf{N}_{\mathrm{cr}} \\
(\mathbf{N} / \mathbf{m})\end{array}$} & \multicolumn{2}{|c|}{$\begin{array}{c}\mathbf{N}_{\mathrm{cr}} \\
(\mathbf{N} / \mathbf{m})\end{array}$} & \multicolumn{2}{|c|}{$\begin{array}{c}\mathbf{N}_{\mathrm{cr}} \\
(\mathbf{N} / \mathbf{m})\end{array}$} & \multicolumn{2}{|c|}{$\begin{array}{c}\mathbf{N}_{\mathrm{cr}} \\
(\mathrm{N} / \mathrm{m})\end{array}$} & \multicolumn{2}{|c|}{$\begin{array}{c}\mathbf{N}_{\mathrm{cr}} \\
(\mathrm{N} / \mathrm{m})\end{array}$} \\
\hline \multirow{2}{*}{1} & Rayleigh-Ritz & \multicolumn{2}{|c|}{87155} & \multicolumn{2}{|c|}{80182} & \multicolumn{2}{|c|}{99333} & \multicolumn{2}{|c|}{99333} & \multicolumn{2}{|c|}{80182} \\
\hline & FEM (ANSYS) & \multicolumn{2}{|c|}{82537} & \multicolumn{2}{|c|}{73442} & \multicolumn{2}{|c|}{97414} & \multicolumn{2}{|c|}{97414} & \multicolumn{2}{|c|}{73442} \\
\hline \multirow{2}{*}{1.2} & Rayleigh-Ritz & \multicolumn{2}{|c|}{69227} & \multicolumn{2}{|c|}{64974} & \multicolumn{2}{|c|}{81887} & \multicolumn{2}{|c|}{84621} & \multicolumn{2}{|c|}{70807} \\
\hline & FEM (ANSYS) & \multicolumn{2}{|c|}{65368} & \multicolumn{2}{|c|}{59334} & \multicolumn{2}{|c|}{80392} & \multicolumn{2}{|c|}{83119} & \multicolumn{2}{|c|}{65484} \\
\hline
\end{tabular}


Table 13 - Critical buckling load $(\mathrm{N} / \mathrm{m})$, short edge is on the y axis (continued)

\begin{tabular}{|c|c|c|c|c|c|c|c|c|c|c|c|}
\hline \multirow{3}{*}{$\mathbf{a} / \mathbf{b}$} & \multirow{3}{*}{ Method } & \multicolumn{10}{|c|}{ Plate Types } \\
\hline & & LT1 & L15 & LT2 & L16 & LT3 & LT13 & LT4 & LT14 & LT5 & LT18 \\
\hline & & \multicolumn{2}{|c|}{$\begin{array}{c}\mathbf{N}_{\mathrm{cr}} \\
(\mathbf{N} / \mathbf{m})\end{array}$} & \multicolumn{2}{|c|}{$\begin{array}{c}\mathbf{N}_{\mathrm{cr}} \\
(\mathbf{N} / \mathbf{m})\end{array}$} & \multicolumn{2}{|c|}{$\begin{array}{c}\mathbf{N}_{\mathrm{cr}} \\
(\mathbf{N} / \mathbf{m})\end{array}$} & \multicolumn{2}{|c|}{$\begin{array}{c}\mathbf{N}_{\mathrm{cr}} \\
(\mathbf{N} / \mathbf{m})\end{array}$} & \multicolumn{2}{|c|}{$\begin{array}{c}\mathbf{N}_{\mathrm{cr}} \\
(\mathbf{N} / \mathbf{m})\end{array}$} \\
\hline \multirow{2}{*}{1.4} & Rayleigh-Ritz & \multicolumn{2}{|c|}{57983} & \multicolumn{2}{|c|}{55779} & \multicolumn{2}{|c|}{70215} & \multicolumn{2}{|c|}{74596} & \multicolumn{2}{|c|}{65088} \\
\hline & FEM (ANSYS) & \multicolumn{2}{|c|}{54732} & \multicolumn{2}{|c|}{51060} & \multicolumn{2}{|c|}{69017} & \multicolumn{2}{|c|}{73390} & \multicolumn{2}{|c|}{60832} \\
\hline \multirow{2}{*}{1.6} & Rayleigh-Ritz & \multicolumn{2}{|c|}{50452} & \multicolumn{2}{|c|}{49816} & \multicolumn{2}{|c|}{61978} & & 424 & & 335 \\
\hline & FEM (ANSYS) & 476 & & & & & 998 & & 436 & & 880 \\
\hline & Rayleigh-Ritz & 451 & 66 & & & & 944 & & 118 & & 738 \\
\hline 1.8 & FEM (ANSYS) & 428 & 312 & & & & 131 & & 295 & & 889 \\
\hline 2 & Rayleigh-Ritz & 413 & & & & & 398 & & 090 & & 866 \\
\hline 2 & FEM (ANSYS) & 392 & & & & & 714 & & 394 & & 482 \\
\hline & & & & & & Plat & Types & & & & \\
\hline $\mathbf{a} / \mathbf{h}$ & Methed & LT6 & LT17 & LT7 & LT9 & LT8 & LT10 & LT11 & LT12 & LT19 & LT24 \\
\hline $\mathbf{a} / \mathbf{D}$ & Inetnod & $\begin{array}{r}\mathbf{N} \\
(\mathbf{N} / \\
\end{array}$ & & & & & $\begin{array}{l}\text { Ner } \\
\text { / } / \mathbf{m})\end{array}$ & & $\begin{array}{l}\text { Ifr } \\
\text { /m) }\end{array}$ & & (cr \\
\hline 1 & Rayleigh-Ritz & 871 & 55 & & & & 224 & & 872 & & 224 \\
\hline 1 & FEM (ANSYS) & 825 & & & & & 478 & & 591 & & 478 \\
\hline 12 & Rayleigh-Ritz & 777 & & & & & 645 & & 557 & & 487 \\
\hline 1.2 & FEM (ANSYS) & 741 & 10 & & & & 215 & & 356 & & 102 \\
\hline 14 & Rayleigh-Ritz & 715 & & & & & 751 & & 745 & & 886 \\
\hline 1.4 & FEM (ANSYS) & 686 & & & & & 561 & & 595 & & 764 \\
\hline 16 & Rayleigh-Ritz & 673 & & & & & 755 & & 028 & & 214 \\
\hline 1.0 & FEM (ANSYS) & 649 & & & & & 3754 & & 912 & & 287 \\
\hline & Rayleigh-Ritz & 642 & & & & & 901 & & 895 & & 966 \\
\hline 1.8 & FEM (ANSYS) & 623 & & & & & 5053 & & 802 & & 185 \\
\hline & Rayleigh-Ritz & 610 & & & & & 304 & & 618 & & 915 \\
\hline 2 & FEM (ANSYS) & 603 & & & & & 578 & & 542 & & 246 \\
\hline & & & & & & Plat & Types & & & & \\
\hline $\mathbf{a} / \mathbf{h}$ & Method & LT20 & LT23 & LT21 & LT22 & & T25 & & $\Gamma 26$ & LT27 & LT28 \\
\hline $\mathbf{a} / \mathbf{D}$ & Dinetinod & $\begin{array}{r}\mathbf{N} \\
(\mathbf{N} / \\
\end{array}$ & & & & & $\begin{array}{l}\mathbf{N} \\
\mathrm{J} / \mathbf{m})\end{array}$ & & $\begin{array}{l}\text { (m) } \\
\end{array}$ & & (cr \\
\hline & Rayleigh-Ritz & 788 & & & & & 516 & & 516 & 103 & 747 \\
\hline 1 & FEM (ANSYS) & 779 & 000 & & & & 399 & & 399 & 100 & 801 \\
\hline 12 & Rayleigh-Ritz & 752 & & & & & 3739 & & 995 & 86 & 698 \\
\hline 1.2 & FEM (ANSYS) & 744 & & & & & 3629 & & 937 & & 345 \\
\hline & Rayleigh-Ritz & 733 & 373 & & & & 3663 & & 440 & & 887 \\
\hline 1.4 & FEM (ANSYS) & 727 & & & & & 3557 & & 412 & & 975 \\
\hline & Rayleigh-Ritz & 723 & 35 & & & & 539 & & 112 & & 343 \\
\hline 1.6 & FEM (ANSYS) & 717 & 788 & & & & 434 & & 100 & & 766 \\
\hline 18 & Rayleigh-Ritz & 717 & 728 & & & & 684 & & 375 & & 974 \\
\hline 1.8 & FEM (ANSYS) & 712 & 259 & & & & 578 & & 373 & 58 & 656 \\
\hline$?$ & Rayleigh-Ritz & 713 & 57 & & & & 833 & & 461 & 55 & 115 \\
\hline 2 & FEM (ANSYS) & $70 s$ & 46 & & & & 723 & & 466 & & 001 \\
\hline
\end{tabular}


Buckling Analysis of Symmetrically Laminated Rectangular Thin Plates Under ...

Table 14 - Critical buckling load (N/m), short edge is on the $x$ axis

\begin{tabular}{|c|c|c|c|c|c|c|c|c|c|c|c|}
\hline \multirow{3}{*}{$\mathbf{b} / \mathbf{a}$} & \multirow{3}{*}{ Method } & \multicolumn{10}{|c|}{ Plate Types } \\
\hline & & LT1 & L15 & LT2 & L16 & LT3 & LT13 & LT4 & LT14 & LT5 & LT18 \\
\hline & & \multicolumn{2}{|c|}{$\begin{array}{c}\mathbf{N}_{\mathrm{cr}} \\
(\mathrm{N} / \mathbf{m})\end{array}$} & \multicolumn{2}{|c|}{$\begin{array}{c}\mathbf{N}_{\mathrm{cr}} \\
(\mathrm{N} / \mathrm{m})\end{array}$} & \multicolumn{2}{|c|}{$\begin{array}{c}N_{\text {cr }} \\
(\mathbf{N} / \mathbf{m})\end{array}$} & \multicolumn{2}{|c|}{$\begin{array}{c}N_{\text {cr }} \\
(\mathbf{N} / \mathbf{m})\end{array}$} & \multicolumn{2}{|c|}{$\begin{array}{c}N_{\text {rr }} \\
(\mathrm{N} / \mathbf{m})\end{array}$} \\
\hline \multirow{2}{*}{1} & Rayleigh-Ritz & \multicolumn{2}{|c|}{87155} & \multicolumn{2}{|c|}{80182} & \multicolumn{2}{|c|}{99333} & \multicolumn{2}{|c|}{99333} & \multicolumn{2}{|c|}{80182} \\
\hline & FEM (ANSYS) & \multicolumn{2}{|c|}{82537} & \multicolumn{2}{|c|}{73442} & \multicolumn{2}{|c|}{97414} & \multicolumn{2}{|c|}{97414} & \multicolumn{2}{|c|}{73442} \\
\hline \multirow{2}{*}{1.2} & Rayleigh-Ritz & \multicolumn{2}{|c|}{77739} & \multicolumn{2}{|c|}{70807} & \multicolumn{2}{|c|}{84621} & \multicolumn{2}{|c|}{81887} & \multicolumn{2}{|c|}{64974} \\
\hline & FEM (ANSYS) & 741 & 10 & & 84 & & 119 & & 392 & & 334 \\
\hline 1 & Rayleigh-Ritz & 715 & 597 & & 88 & & 596 & & 215 & & 779 \\
\hline 1.4 & FEM (ANSYS) & 686 & & & 32 & & 390 & & 017 & & 060 \\
\hline & Rayleigh-Ritz & 673 & 40 & & 35 & & 424 & & 978 & & 816 \\
\hline 1.0 & FEM (ANSYS) & 649 & 81 & & 80 & & 436 & & 998 & & 855 \\
\hline 10 & Rayleigh-Ritz & 642 & 265 & 58 & 38 & & 118 & & 944 & & 745 \\
\hline 1.8 & FEM (ANSYS) & 623 & 14 & & 89 & & 295 & & 131 & & 401 \\
\hline ? & Rayleigh-Ritz & 619 & & & 66 & & 090 & & 398 & & 852 \\
\hline 2 & FEM (ANSYS) & 603 & & 54 & 82 & & 394 & & 714 & & 007 \\
\hline & & & & & & Plat & Types & & & & \\
\hline b/a & Mothod & LT6 & LT17 & LT7 & LT9 & LT8 & LT10 & LT11 & LT12 & LT19 & LT24 \\
\hline D/a & pretmou & $\begin{array}{r}\mathbf{N} \\
(\mathbf{N} /\end{array}$ & & & & & $\begin{array}{l}\text { ver } \\
/ \mathbf{m})\end{array}$ & & $\begin{array}{l}\text { Ner } \\
/ \mathbf{m})\end{array}$ & & $\begin{array}{l}\text { Trr } \\
\text { /m) }\end{array}$ \\
\hline 1 & Rayleigh-Ritz & 871 & & & 91 & & 224 & & 872 & & 224 \\
\hline 1 & FEM (ANSYS) & 825 & & & 00 & & 478 & & 591 & & 478 \\
\hline 12 & Rayleigh-Ritz & 692 & & & 51 & & 487 & & 650 & & 645 \\
\hline 1.2 & FEM (ANSYS) & 653 & & & 57 & & 102 & & 424 & & 215 \\
\hline & Rayleigh-Ritz & 579 & & & & & 886 & & 710 & & 751 \\
\hline 1.4 & FEM (ANSYS) & 547 & & & 22 & & 764 & & 522 & & 561 \\
\hline 1 & Rayleigh-Ritz & 504 & 152 & & 35 & & 214 & & 150 & & 755 \\
\hline 1.0 & FEM (ANSYS) & 476 & & & 88 & & 287 & & 987 & & 754 \\
\hline 10 & Rayleigh-Ritz & 451 & 66 & & & & 966 & & 175 & & 901 \\
\hline 1.0 & FEM (ANSYS) & 428 & & & & & 185 & & 031 & & 053 \\
\hline 2 & Rayleigh-Ritz & 413 & & & 57 & & 915 & & 440 & & 304 \\
\hline 2 & FEM (ANSYS) & 392 & & 70 & 46 & & 246 & & 309 & & 578 \\
\hline & & & & & & Plat & Types & & & & \\
\hline $\mathbf{b} / \mathbf{a}$ & Method & LT20 & LT23 & LT21 & LT22 & & $\mathrm{T} 25$ & & $\Gamma 26$ & LT27 & LT28 \\
\hline & & $\begin{array}{r}\mathbf{N} \\
(\mathrm{N} /\end{array}$ & & & & & $\begin{array}{l}\mathrm{N}_{\mathrm{cr}} \\
/ / \mathbf{m})\end{array}$ & & $\begin{array}{l}\text { (m) } \\
\text { /m) }\end{array}$ & & $\begin{array}{l}\text { Ter } \\
\text { /m) }\end{array}$ \\
\hline 1 & Rayleigh-Ritz & 788 & 391 & & 72 & & 516 & & 516 & 10 & 747 \\
\hline 1 & FEM (ANSYS) & 779 & 00 & & & & 399 & & 399 & 10 & 801 \\
\hline 1 & Rayleigh-Ritz & 589 & 32 & & 57 & & 995 & & 739 & & 698 \\
\hline 1.2 & FEM (ANSYS) & 581 & 64 & 53 & 56 & & 937 & & 629 & & 345 \\
\hline
\end{tabular}


Table 14 - Critical buckling load $(\mathrm{N} / \mathrm{m})$, short edge is on the x axis (continue)

\begin{tabular}{|c|c|c|c|c|c|c|c|c|}
\hline \multirow{3}{*}{$\mathbf{b} / \mathbf{a}$} & \multirow{3}{*}{ Method } & \multicolumn{7}{|c|}{ Plate Types } \\
\hline & & LT20 & LT23 & \begin{tabular}{l|l} 
LT21 & LT22
\end{tabular} & LT25 & LT26 & LT27 & LT28 \\
\hline & & \multicolumn{2}{|c|}{$\begin{array}{c}\mathbf{N}_{\mathrm{cr}} \\
(\mathbf{N} / \mathbf{m})\end{array}$} & $\begin{array}{c}N_{\text {cr }} \\
(\mathrm{N} / \mathrm{m})\end{array}$ & $\begin{array}{c}\mathbf{N}_{\mathrm{cr}} \\
(\mathrm{N} / \mathrm{m})\end{array}$ & $\begin{array}{c}\mathbf{N}_{\mathrm{cr}} \\
(\mathrm{N} / \mathrm{m})\end{array}$ & \multicolumn{2}{|c|}{$\begin{array}{c}\mathbf{N}_{\mathrm{cr}} \\
(\mathrm{N} / \mathrm{m})\end{array}$} \\
\hline \multirow{2}{*}{1.4} & Rayleigh-Ritz & \multicolumn{2}{|c|}{47234} & 46745 & 41440 & 58663 & \multicolumn{2}{|c|}{74887} \\
\hline & FEM (ANSYS) & \multicolumn{2}{|c|}{46615} & 46595 & 41412 & 58557 & \multicolumn{2}{|c|}{72975} \\
\hline \multirow{2}{*}{1.6} & Rayleigh-Ritz & \multicolumn{2}{|c|}{39844} & 43028 & 38112 & 59539 & \multicolumn{2}{|c|}{66343} \\
\hline & FEM (ANSYS) & \multicolumn{2}{|c|}{39335} & 42912 & 38100 & 59434 & \multicolumn{2}{|c|}{64766} \\
\hline \multirow{2}{*}{1.8} & Rayleigh-Ritz & \multicolumn{2}{|c|}{34902} & 40895 & 36375 & 60684 & \multicolumn{2}{|c|}{59974} \\
\hline & FEM (ANSYS) & \multicolumn{2}{|c|}{34476} & 40802 & 36373 & 60578 & \multicolumn{2}{|c|}{58656} \\
\hline \multirow{2}{*}{2} & Rayleigh-Ritz & \multicolumn{2}{|c|}{31444} & 39618 & 35461 & 61833 & \multicolumn{2}{|c|}{55115} \\
\hline & FEM (ANSYS) & \multicolumn{2}{|c|}{31085} & 39542 & 35466 & 61723 & \multicolumn{2}{|c|}{54001} \\
\hline
\end{tabular}

\subsubsection{Non-dimensional results}

Non-dimensional critical buckling loads of symmetrically laminated composite plates are tabulated for practical data for designer and given in Table 15 and 16.

Table 15 - Non-dimensional critical buckling load, short edge is on the $x$ axis,

$$
N_{c r}^{\prime}=N_{c r} \frac{b^{2}}{t^{3} E_{22}}
$$

\begin{tabular}{|c|c|c|c|c|c|c|}
\hline \multirow{3}{*}{ Plate Type } & \multicolumn{6}{|c|}{ Aspect ratio } \\
\hline & \multicolumn{6}{|c|}{$\mathbf{a} / \mathbf{b}$} \\
\hline & 1 & 1,2 & 1,4 & 1,6 & 1,8 & 2 \\
\hline LT1 & \multirow{2}{*}{45158} & \multirow{2}{*}{35869} & \multirow{2}{*}{30043} & \multirow{2}{*}{26141} & \multirow{2}{*}{23402} & \multirow{2}{*}{21410} \\
\hline LT15 & & & & & & \\
\hline LT2 & \multirow{2}{*}{41545} & \multirow{2}{*}{33665} & \multirow{2}{*}{28901} & \multirow{2}{*}{25811} & \multirow{2}{*}{23702} & \multirow{2}{*}{22203} \\
\hline LT16 & & & & & & \\
\hline LT3 & \multirow{2}{*}{51468} & \multirow{2}{*}{42428} & \multirow{2}{*}{36381} & \multirow{2}{*}{32113} & \multirow{2}{*}{28987} & \multirow{2}{*}{26631} \\
\hline LT13 & & & & & & \\
\hline LT4 & \multirow{2}{*}{51468} & \multirow{2}{*}{43845} & \multirow{2}{*}{38651} & \multirow{2}{*}{34935} & \multirow{2}{*}{32185} & \multirow{2}{*}{30098} \\
\hline LT14 & & & & & & \\
\hline LT5 & \multirow{2}{*}{41545} & \multirow{2}{*}{36688} & \multirow{2}{*}{33724} & \multirow{2}{*}{31780} & \multirow{2}{*}{30434} & \multirow{2}{*}{29464} \\
\hline LT18 & & & & & & \\
\hline LT6 & \multirow{2}{*}{45158} & \multirow{2}{*}{40279} & \multirow{2}{*}{37097} & \multirow{2}{*}{34891} & 33208 & 32100 \\
\hline LT17 & & & & & 35290 & 52109 \\
\hline LT7 & 10076 & 20525 & 21174 & 20645 & 10084 & 16200 \\
\hline LT9 & 40010 & נדנה & ד & $2007 \mathrm{~J}$ & 10007 & 10242 \\
\hline
\end{tabular}


Buckling Analysis of Symmetrically Laminated Rectangular Thin Plates Under ...

Table 15 - Non-dimensional critical buckling load, short edge is on the $x$ axis,

$$
N_{c r}^{\prime}=N_{c r} \frac{b^{2}}{t^{3} E_{22}} \text { (continued) }
$$

\begin{tabular}{|c|c|c|c|c|c|c|}
\hline \multirow{3}{*}{ Plate Type } & \multicolumn{6}{|c|}{ Aspect ratio } \\
\hline & \multicolumn{6}{|c|}{$\mathbf{a} / \mathbf{b}$} \\
\hline & 1 & 1,2 & 1,4 & 1,6 & 1,8 & 2 \\
\hline LT8 & \multirow{2}{*}{37940} & \multirow{2}{*}{28832} & \multirow{2}{*}{23705} & \multirow{2}{*}{20598} & \multirow{2}{*}{18602} & \multirow{2}{*}{17256} \\
\hline LT10 & & & & & & \\
\hline LT11 & \multirow{2}{*}{34649} & \multirow{2}{*}{27750} & \multirow{2}{*}{24220} & \multirow{2}{*}{22294} & \multirow{2}{*}{21189} & \multirow{2}{*}{20527} \\
\hline LT12 & & & & & & \\
\hline LT19 & \multirow{2}{*}{37940} & \multirow{2}{*}{36004} & \multirow{2}{*}{35174} & \multirow{2}{*}{34826} & \multirow{2}{*}{34697} & \multirow{2}{*}{34671} \\
\hline LT24 & & & & & & \\
\hline LT20 & \multirow{2}{*}{40876} & \multirow{2}{*}{38990} & \multirow{2}{*}{38017} & \multirow{2}{*}{37479} & \multirow{2}{*}{37165} & \multirow{2}{*}{36973} \\
\hline LT23 & & & & & & \\
\hline LT21 & \multirow{2}{*}{34649} & \multirow{2}{*}{31943} & \multirow{2}{*}{30938} & \multirow{2}{*}{30648} & \multirow{2}{*}{30661} & \multirow{2}{*}{30798} \\
\hline LT22 & & & & & & \\
\hline LT25 & 31874 & 30435 & 30395 & 30849 & 31443 & 32038 \\
\hline LT26 & 31874 & 24868 & 21472 & 19747 & 18847 & 18374 \\
\hline LT27 & \multirow{2}{*}{53755} & \multirow{2}{*}{44921} & \multirow{2}{*}{38802} & \multirow{2}{*}{34375} & & \\
\hline LT28 & & & & & $310 / 2$ & ו 285 \\
\hline
\end{tabular}

Table 16 - Non-dimensional critical buckling load, short edge is on the y axis,

$$
N_{c r}^{\prime}=N_{c r} \frac{a^{2}}{t^{3} E_{22}}
$$

\begin{tabular}{|c|c|c|c|c|c|c|}
\hline \multirow{3}{*}{ Plate Type } & \multicolumn{6}{|c|}{ Aspect ratio } \\
\hline & \multicolumn{6}{|c|}{$\mathbf{b} / \mathbf{a}$} \\
\hline & 1 & 1,2 & 1,4 & 1,6 & 1,8 & 2 \\
\hline LT1 & \multirow[b]{2}{*}{45158} & \multirow[b]{2}{*}{40279} & \multirow[b]{2}{*}{37097} & \multirow[b]{2}{*}{34891} & \multirow[b]{2}{*}{33298} & \multirow[b]{2}{*}{32109} \\
\hline LT15 & & & & & & \\
\hline LT2 & \multirow[b]{2}{*}{41545} & \multirow[b]{2}{*}{36688} & \multirow[b]{2}{*}{33724} & \multirow[b]{2}{*}{31780} & \multirow[b]{2}{*}{30434} & \multirow[b]{2}{*}{29464} \\
\hline LT16 & & & & & & \\
\hline LT3 & \multirow[b]{2}{*}{51468} & \multirow[b]{2}{*}{43845} & \multirow[b]{2}{*}{38651} & \multirow[b]{2}{*}{34935} & \multirow[b]{2}{*}{32185} & \multirow[b]{2}{*}{30098} \\
\hline LT13 & & & & & & \\
\hline LT4 & \multirow[b]{2}{*}{51468} & \multirow[b]{2}{*}{42428} & \multirow[b]{2}{*}{36381} & \multirow[b]{2}{*}{32113} & \multirow[b]{2}{*}{28987} & \multirow[b]{2}{*}{26631} \\
\hline LT14 & & & & & & \\
\hline LT5 & \multirow[b]{2}{*}{41545} & \multirow[b]{2}{*}{33665} & \multirow[b]{2}{*}{28901} & \multirow[b]{2}{*}{25811} & \multirow[b]{2}{*}{23702} & \multirow[b]{2}{*}{22203} \\
\hline LT18 & & & & & & \\
\hline
\end{tabular}


Table 16 - Non-dimensional critical buckling load, short edge is on the y axis,

$$
N_{c r}^{\prime}=N_{c r} \frac{a^{2}}{t^{3} E_{22}} \text { (continued) }
$$

\begin{tabular}{|c|c|c|c|c|c|c|}
\hline \multirow{3}{*}{ Plate Type } & \multicolumn{6}{|c|}{ Aspect ratio } \\
\hline & \multicolumn{6}{|c|}{$\mathbf{b} / \mathbf{a}$} \\
\hline & 1 & 1,2 & 1,4 & 1,6 & 1,8 & 2 \\
\hline LT6 & \multirow[b]{2}{*}{45158} & \multirow[b]{2}{*}{35869} & \multirow[b]{2}{*}{30043} & \multirow[b]{2}{*}{26141} & \multirow[b]{2}{*}{23402} & \multirow[b]{2}{*}{21410} \\
\hline LT17 & & & & & & \\
\hline LT7 & \multirow[b]{2}{*}{40876} & \multirow[b]{2}{*}{38990} & \multirow[b]{2}{*}{38017} & \multirow[b]{2}{*}{37479} & \multirow[b]{2}{*}{37165} & \multirow[b]{2}{*}{36973} \\
\hline LT9 & & & & & & \\
\hline LT8 & \multirow[b]{2}{*}{37940} & \multirow[b]{2}{*}{36004} & \multirow[b]{2}{*}{35174} & \multirow[b]{2}{*}{34826} & \multirow[b]{2}{*}{34697} & \multirow[b]{2}{*}{34671} \\
\hline LT10 & & & & & & \\
\hline LT11 & \multirow[b]{2}{*}{34649} & \multirow[b]{2}{*}{31943} & \multirow[b]{2}{*}{30938} & \multirow[b]{2}{*}{30648} & \multirow[b]{2}{*}{30661} & \multirow[b]{2}{*}{30798} \\
\hline LT12 & & & & & & \\
\hline LT19 & \multirow[b]{2}{*}{37940} & \multirow[b]{2}{*}{28832} & \multirow[b]{2}{*}{23705} & \multirow[b]{2}{*}{20598} & \multirow[b]{2}{*}{18602} & \multirow[b]{2}{*}{17256} \\
\hline LT24 & & & & & & \\
\hline LT20 & \multirow[b]{2}{*}{40876} & \multirow[b]{2}{*}{30535} & & & & \\
\hline LT23 & & & 24474 & 20645 & 18084 & 16292 \\
\hline LT21 & & & & & & \\
\hline LT22 & 34649 & 27750 & 24220 & 22294 & 21189 & 20527 \\
\hline LT25 & 31874 & 24868 & 21472 & 19747 & 18847 & 18374 \\
\hline LT26 & 31874 & 30435 & 30395 & 30849 & 31443 & 32038 \\
\hline LT27 & & & & & & \\
\hline LT28 & 53755 & 44921 & 38802 & 34375 & 31075 & 28557 \\
\hline
\end{tabular}

\section{CONCLUSIONS}

Biaxial buckling analysis of symmetrically laminated quasi-isotropic, cross-ply and angleply rectangular thin plates has been examined in this study. Plates were considered as simply supported at the edges. Effects of thickness, aspect ratios and lamination types on critical buckling loads have been investigated parametrically by Rayleigh Ritz Method based on the Classical Lamination Plate Theory (CLPT). The Finite Element Method software package ANSYS has been used for verification calculations in order to compare the results. Good correlation was obtained.

For the calculation of Rayleigh Ritz Method integral equations were initially solved by using Mathematica [49] then the code prepared by using the MATLAB [50] programming language for different conditions. Results obtained using Rayleigh Ritz Method were obtained much faster than those of FEM calculations with ANSYS software package.

The critical buckling load of isotropic plates increases with decreasing of the aspect ratio $(\mathrm{a} / \mathrm{b}$ or b/a). This situation was observed for the symmetrically composite laminates (Cross-Ply, Angle-Ply and Quasi-isotropic plates) similarly. 
The present paper also indicates that the thick plates have a larger buckling strength compared to thin plates. However, shear deformable theories should be considered for thick plates.

Symmetrically laminated cross-ply plates are orthotropic and their bending-twisting coupling terms $\mathrm{D}_{16}$ and $\mathrm{D}_{26}$ are zero, but these terms are taken into account for quasi-isotropic and angle-ply laminates. Jones [51] mentioned that for laminated plates with bending-twisting coupling decrease buckling loads. The same situation was observed that considering Angleply and Quasi-isotropic plates for four-terms solutions in this study. When the bendingtwisting coupling terms $\left(\mathrm{D}_{16}, \mathrm{D}_{26}\right)$ are not taken into account, the critical buckling load is higher.

Results show that bending stiffness matrix elements $\mathrm{D}_{11}$ and $\mathrm{D}_{22}$ are equal for symmetrically laminated Angle-Ply plates (LT27 $=\left[-45_{2} / 45_{2} /-45_{2} / 45_{2}\right]_{\mathrm{s}}$ and LT28 $=\left[45_{2} /-45_{2} / 45_{2} /-45_{2}\right]_{\mathrm{s}}$ ) similar to isotropic plates. Thus, the critical buckling load for equal aspect ratios $(a / b=b / a)$ gives the same result for angle-ply plates and isotropic plates. One of the most important results of this study is that, in terms of largest value for the lowest critical buckling loads $\left(\mathrm{N}_{\mathrm{cr}}\right)$, the angle-ply plates are more advantageous than Cross-ply and Quasi-isotropic plates for lowest aspect ratio is $(\mathrm{a} / \mathrm{b}=1,1.2$ and 1.4). Symmetrically laminated Quasi-isotropic plates have the highest value for the fundamental critical buckling loads for highest aspect ratios $(\mathrm{a} / \mathrm{b}=1.6,1.8$ and 2$)$. It is demonstrated that the bending stiffness matrix elements play an important role in the bi-axial buckling of symmetrically laminated plates.

It was aimed to determine the most appropriate stiffest plate types (having highest value for the lowest critical buckling loads) and this aim was accomplished for all conditions (results given in Section 3).

Therefore, it can be concluded that the most suitable plate types may be quickly determined at the design stage of composite engineering structures, with the use of tabulated nondimensional results obtained by the Rayleigh Ritz method. In addition, the tabulated results should be valuable to engineers as well as researchers working in this field.

Some mode shapes of Quasi-isotropic, Cross-ply and Angle-ply laminates have been obtained and given in Appendix (Figure A1 and Figure A2).

In future studies, stress and strain distributions along the thickness of laminated plates and failure theories can be examined, supported by experimental studies and advantageous lamination types can be investigated by optimization techniques.

\section{Acknowledgements}

The authors thank Prof. Dr. İzzet Deniz ÜNSALAN (Dokuz Eylul University) for his valuable help.

\section{References}

[1] Lekhnitskii, S. G., Anisotropic plates, second ed, translated from the Russian by S. W. Tsai and T. Cheron, Gordon and Breach, New York.,1968.

[2] Ambartsumyan, S. A., Theory of anisotropic plates, Technomic Publishing, Stamford CT., 1970. 
[3] Ashton, J. E. and Whitney, J. M., Theory of laminated plates, Technomic [43 Publishing, Stamford CT. 1970.

[4] Szilard R., Theory and analysis of plates: classical and numerical methods. Englewood Cliffs, New Jersey: Prentice-Hall, 1974.

[5] Jones, R. M., Mechanics of composite materials, Scripta, Washington DC, 1975.

[6] Chia, C.Y, Nonlinear analysis of plates, McGraw-Hill, New York, 1980.

[7] Leissa, A. W., A review of laminated composite plate buckling, Appl Mech Rev vol 40, no 5, May, 575-591, 1987.

[8] Tung, T. K. and Surdenas, J., Buckling of Rectangular Orthotropic Plates Under Biaxial Loading, Journal of Composite Materials, Vol. 21-February, 124-128, 1987.

[9] Nagendra, S., Haftka, R.T. and Gurdal, Z., Stacking sequence optimization of simply supported laminates with stability and strain constraints, AIAA-92-2310-CP-2526$2535,1992$.

[10] Zhang, J.W., Buckling and Postbuckling of Unsymmetrically Laminated Angle-ply Plates in Uniaxial and Biaxial Compression, Thin- Walled Structures 15, 271-290, 1993.

[11] Kim Y.S. and Hoa S.V., Bi-axial buckling behavior of composite rectangular plates, Composite Structures 31, 247-252, 1995.

[12] Nair, S., Singh, G.L. and G. Rao, V., Stability of Laminated Composite Plates Subjected To Various Types of In-Plane Loadings, Int. J. Mech. Sci., Vol. 38. No. 2, pp. 191-202, 1996.

[13] Sundaresan,P., Singh, G. and Rao,G.V., Buckling and post-buckling analysis of moderately thick laminated rectangular plates, Computers \& Structures Vol. 61, No. I, pp.79-86, 1996.

[14] Walker,M., Adali, S. and Verijenko,V., Optimization of symmetric laminates for maximum buckling load including the effects of bending-twisting coupling, Computers\&Structures, Vol.58, No.2, pp.313-319, 1996a.

[15] Walker, M., Adali, S. and Verijenko, V. E., Optimal design of symmetric angle-ply laminates subject to nonuniform buckling loads and in-plane restraints, Thin-Walled Structures Vol.26, No. I, pp. 45 60, 1996b.

[16] Adali,S., Richter,A. and Verijenko, K.E., Optimization of shear-deformable laminated plates under buckling and strength criteria, Composite Structures Vol. 39, No.3-4, pp. 167-178, 1997.

[17] Durban, D. and Zuckerman, Z., Elastoplastic buckling of rectangular plates in biaxial compression/tension, International Journal of Mechanical Sciences 41, 751-765, 1999.

[18] Sarma, M.A., Singh, G. and Rao,G.V., Stability behaviour of angle ply plates subjected to various types of inplane loadings, Indian Journal of Engineering\& Materials Sciences, Vol.6, August, pp.173-181, 1999. 
[19] Tuttle, M., Singhatanadgid, P. and Hinds, G., Buckling of Composite Panels Subjected to Biaxial Loading, Experimental Mechanics, VoI. 39, No. 3, September, pp.191-201, 1999.

[20] Kollar, L.P. and Veres, I.A., Buckling of Rectangular Orthotropic Plates Subjected to Biaxial Normal Forces, Journal of Composite Materials, Vol. 35, No. 07, 625-635, 2001.

[21] Romeo, G. and Ferrero, G., Analytical/Experimental Behavior of Anisotropic Rectangular Panels Under Linearly Varying Combined Loads, AIAA Journal, Vol. 39, No. 5, May, 932-941, 2001.

[22] Narita, Y. and Turvey, G. J., Proceedings of the Institution of Mechanical Engineers, Part C: Journal of Mechanical Engineering Science, Maximizing the buckling loads of symmetrically laminated composite rectangular plates using a layerwise optimization approach, 218: 681-691, 2004.

[23] Ni,Q., Xie, J. and Iwamoto, M., Buckling analysis of laminated composite plates with arbitrary edge supports, Composite Structures, 69, 209-217, 2005.

[24] Shukla, K. K., Nath, Y., Kreuzer, E. and Kumar, K.V.S., Buckling of Laminated Composite Rectangular Plates, J. Aerosp. Eng.18, 215-223, 2005.

[25] Timarci, T. and Aydogdu, M., Buckling of symmetric cross-ply square plates with various boundary conditions, Composite Structures 68, 381-389, 2005.

[26] Bert, C.W. and Malik,M., On the buckling characteristics of symmetrically laminated cross-ply plates, Mechanics of Composite Materials and Structures, 4:1, 39-67, 2007.

[27] Qiao, P. and Shan,L., Explicit local buckling analysis of rotationally restrained composite plates under biaxial loading, International Journal of Structural Stability and Dynamics, Vol. 7, No. 3, 487-517, 2007

[28] Aktaş,M., Buckling Behaviour Of Carbon/Epoxy Laminated Composite Plates Under Biaxial Loading, Advanced Composites Letters, Vol. 18, Iss. 3, 85-93, 2009.

[29] Latalski, J., Ply Thickness Tolerances In Stacking Sequence Optimization Of Multilayered Laminate Plates, Journal Of Theoretical And Applied Mechanics, 51, 4, pp. 1039-1052, Warsaw, 2013.

[30] Sayyad, A.S. and Ghugal,Y.M., On the Buckling of Isotropic, Transversely Isotropic and Laminated Composite Rectangular Plates, International Journal of Structural Stability and Dynamics, Vol. 14, No. 6, 1450020, 2014.

[31] Bourada,F., Amara, K. and Tounsi, A., Buckling analysis of isotropic and orthotropic plates using a novel four variable refined plate theory, Steel and Composite Structures, Vol. 21, No. 6, 1287-1306, 2016.

[32] Becheri,T. Amara,K., Bouazza, M. and Benseddiq,N., Buckling of symmetrically laminated plates using nth-order shear deformation theory with curvature effects, Steel and Composite Structures, Vol. 21, No. 6, 1347-1368, 2016.

[33] Rajanna, T. , Banerjee,S., Desai, Y.M. and Prabhakara, D.L., Vibration and buckling analyses of laminated panels with and without cutouts under compressive and tensile edge loads, Steel and Composite Structures, Vol. 21, No. 1, 37-55, 2016. 
[34] Belkacem, A., Tahar,H.D., Abderrezak,R., Amine,B.M., Mohamed,Z. and Boussad,A., Mechanical buckling analysis of hybrid laminated composite plates under different boundary conditions, Structural Engineering and Mechanics, Vol. 66, No. 6, 761-769, 2018.

[35] Topal,U., Vo-Duy,T., Dede,T. and Nazarimofrad,E., Buckling load optimization of laminated plates resting on Pasternak foundation using TLBO, Structural Engineering and Mechanics, Vol. 67, No. 6, 617-628, 2018.

[36] Bourada, M., Bouadi,A., Bousahla,A.A., Senouci,A., Bourada,F., Tounsi,A. and Mahmoud, S.R., Buckling behavior of rectangular plates under uniaxial and biaxial compression, Structural Engineering and Mechanics, Vol. 70, No. 1, 113-123, 2019.

[37] Fellah, M., Draiche,K., Houari,M.S.A., Tounsi,A., Saeed,T., Alhodaly, M.Sh. and Benguediab,M., A novel refined shear deformation theory for the buckling analysis of thick isotropic plates, Structural Engineering and Mechanics, Vol. 69, No. 3, 335-345, 2019.

[38] Altekin, M., Bending of super-elliptical Mindlin plates by finite element method, Teknik Dergi, 29, No:4, 8469-8496, 2018.

[39] Altekin, M., Free linear vibration and buckling of super-elliptical plates resting on symmetrically distributed point-supports on the diagonals, Thin-Walled Structures, Vol.46, 10, 1066-1086, 2008.

[40] Altunsaray, E. and Bayer, I., Buckling of symmetrically laminated quasi-isotropic thin rectangular plates, Steel and Composite Structures, Vol. 17, No. 3, 305-320, 2014.

[41] Tsai, S.W., Composites design, (4th Edition), Think Composites, 1988.

[42] Köksal, E. and Köksal, T.Çubuk Plak Kabuk Stabilitesi, Yıldız Teknik Üniversitesi Yayını, Yayın No:309, Yıldız Teknik Üniversitesi Matbaası, İstanbul ,1996 (In Turkish).

[43] Köksal, T., Sonlu Elemanlar Metodu, Yıldız Teknik Üniversitesi Yayını, Yayın No:304, Yıldız Teknik Üniversitesi Matbaası İstanbul ,1996 (In Turkish)

[44] Fish, J. and Belytschko, T., A first cours in Finite Elements, John Wiley\&Sons,Ltd, 2007.

[45] ANSYS 2019.1, Academic version, Dokuz Eylul University, 2019.

[46] Iyengar,N.G.R., Structural stability of columns and plates, John Wiley\&Sons,Ltd, 1988

[47] Reddy, J.N., Mechanics of laminated composite plates and shells: Theory and Analysis (2nd Ed.), Boca Raton, FL: CRC Press, 2004.

[48] Ventsel,E and Krauthammer,T., Thin plates and shells, theory, analysis, and applications, Marcel Dekker Inc., 2001

[49] Wolfram Mathematica 11.3.0, Dokuz Eylul University, 2019.

[50] Matlab R2018a, Dokuz Eylul University, 2019.

[51] Jones, R.M., Mechanics of composite materials, 2nd ed., Taylor\&Francis, 1999. 


\section{APPENDIX}

In this section, critical buckling loads of some plate types for the first three mode shapes are given. It can be seen that the critical buckling load values of some different plate types for some edge ratios are equal. However, it has been observed that this situation may change as the edge ratio changes.

First three modes shapes and buckling loads of some quasi-isotropic, cross-ply and angle-ply laminates are presented in Figure A1 and Figure A2. It can be seen from Figure A1 $(a / b=1)$ the critical buckling loads of LT8 and LT19 are equal but their modes shapes are different. LT27 (Angle-Ply plate) has the highest critical buckling loads for mode-1 and mode-2, while LT25 (Cross-Ply plate) has the highest critical buckling load for mode-3. It may be seen from Figure A2 for a different aspect ratio $(\mathrm{a} / \mathrm{b}=2)$ the critical buckling loads of LT8 and LT19 are different this time. LT27 (Angle-Ply plate) has the highest critical buckling loads for mode1 , mode- 2 and mode- 3 .

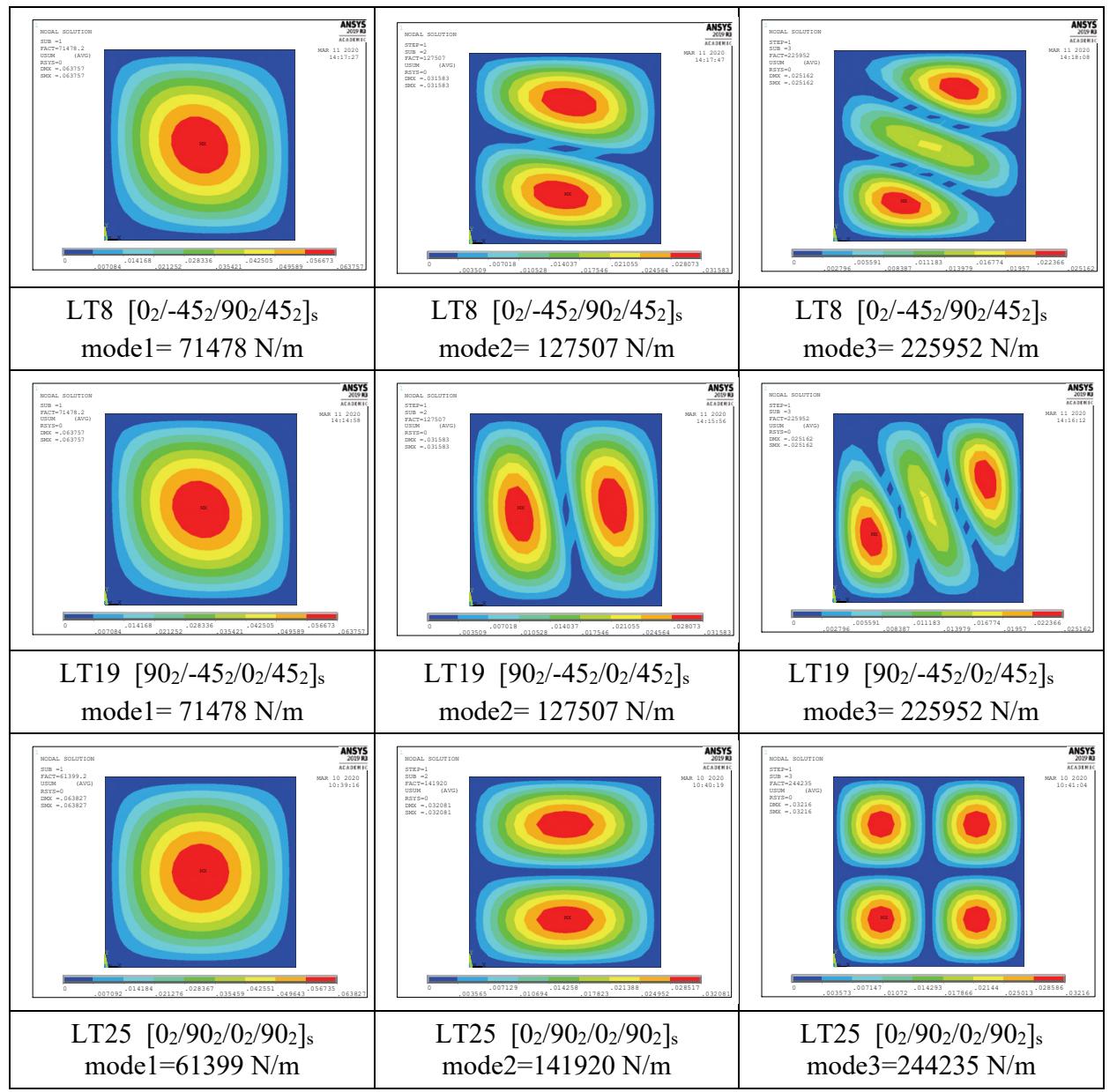




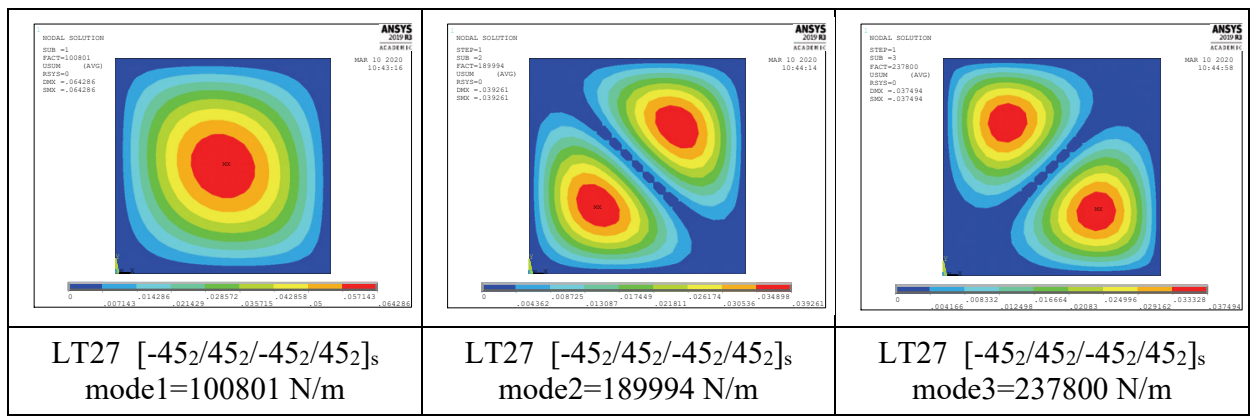

Figure A1 - Some mode shapes of laminated plates (quasi-isotropic, cross-ply, angle-ply) $(a / b=1)$

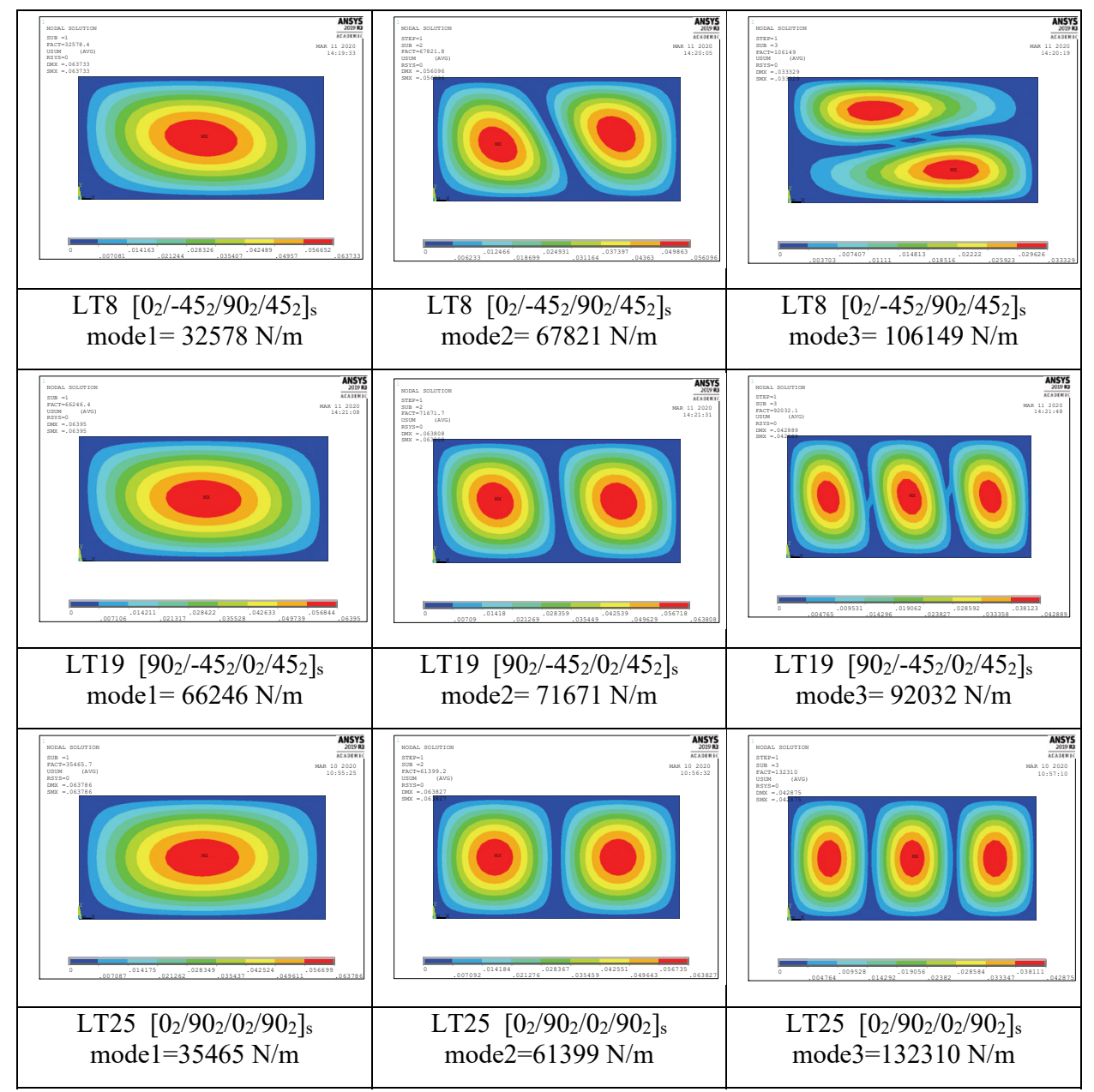


Buckling Analysis of Symmetrically Laminated Rectangular Thin Plates Under ...

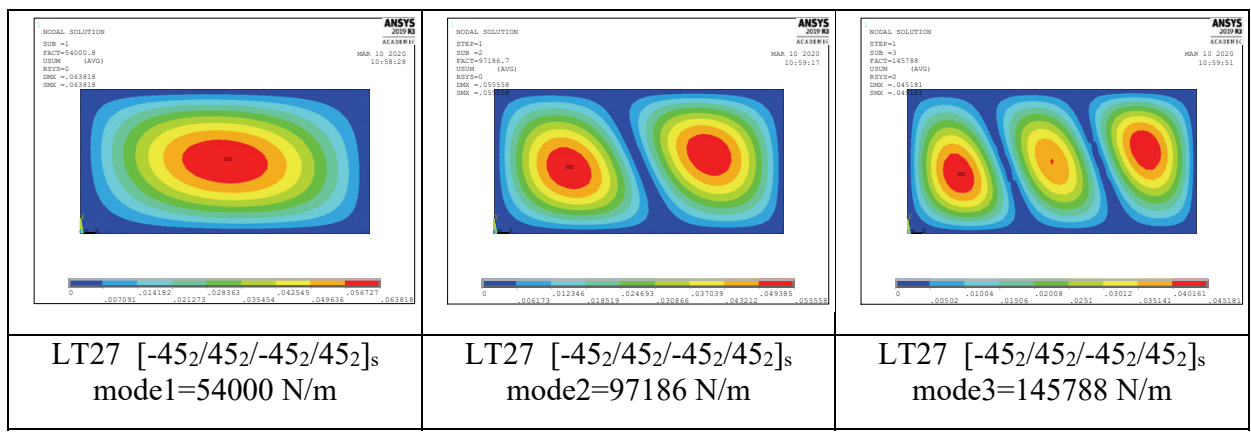

Figure A2 - Some mode shapes of laminated plates (quasi-isotropic, cross-ply, angle-ply) $(a / b=2)$ 